\title{
Credit Default Swaps and Non-GAAP Earnings Disclosure*
}

\author{
Dirk E. Black ${ }^{* *}$ \\ University of Nebraska - Lincoln \\ Kalin S. Kolev \\ Baruch College - CUNY \\ Binghao (Jimmy) Zhao \\ Southwestern University of Finance and Economics
}

May 2020

\begin{abstract}
We examine the effect of credit default swap (CDS) coverage on voluntary disclosure using firmprovided non-GAAP earnings as a laboratory. For a large sample of U.S. firms, we find that for companies with CDS coverage, the persistence of non-GAAP exclusions is lower, implying higher disclosure quality. The effect manifests across a range of performance measures and measurement windows and is strongest among non-investment-grade firms, entities for which monitors are more likely to rely on public accounting reports. This improvement in quality comes as a counterpoint to a decrease in the frequency of non-GAAP disclosure among firms that experience CDS coverage initiation. Collectively, our findings suggest firms counteract the perceived negative externalities associated with CDS coverage with higher-quality voluntary disclosure.
\end{abstract}

JEL codes: G14; M21; M41

Keywords: non-GAAP earnings; non-GAAP exclusions; credit default swaps; voluntary disclosure quality

\footnotetext{
*Acknowledgements: We appreciate the comments and suggestions of Kimball Chapman, Stuart Dearden, Jimmy Downes, Amanda Gonzales, Jeff McMullin, Xiao Song, Thomas Steffen, John Treu, and the workshop participants at the 2019 Baruch-Fordham-Rutgers Conference, the 2019 BYU Accounting Research Symposium, and the University of Nebraska - Lincoln. Black acknowledges the financial support of the School of Accountancy at the University of Nebraska - Lincoln. Kolev acknowledges the financial support of Baruch College - CUNY and the PSC-CUNY Research Award Program. All errors are ours.

${ }^{* *}$ Contact information: Dirk Black, 402-472-2927, dirkblack@unl.edu; Kalin Kolev, 646-312-3196, kalin.kolev@baruch.cuny.edu; Binghao Zhao, zhaobh@swufe.edu.cn.
} 


\title{
Credit Default Swaps and Non-GAAP Earnings Disclosure
}

\begin{abstract}
We examine the effect of credit default swap (CDS) coverage on voluntary disclosure using firmprovided non-GAAP earnings as a laboratory. For a large sample of U.S. firms, we find that for companies with CDS coverage, the persistence of non-GAAP exclusions is lower, implying higher disclosure quality. The effect manifests across a range of performance measures and measurement windows and is strongest among non-investment-grade firms, entities for which monitors are more likely to rely on public accounting reports. This improvement in quality comes as a counterpoint to a decrease in the frequency of non-GAAP disclosure among firms that experience CDS coverage initiation. Collectively, our findings suggest firms counteract the perceived negative externalities associated with CDS coverage with higher-quality voluntary disclosure.
\end{abstract}

JEL codes: G14; M21; M41

Keywords: non-GAAP earnings; non-GAAP exclusions; credit default swaps; voluntary disclosure quality 


\section{Introduction}

We study the interplay between credit default swap (CDS) coverage and the quality of voluntary disclosure using manager-provided non-GAAP earnings as a laboratory. Specifically, we test whether the quality of non-GAAP earnings, represented by the association between items excluded from GAAP earnings to calculate non-GAAP earnings and measures of future performance, changes with CDS coverage. We conduct the examination to inform the active debate on how the reference (i.e., CDS-covered) entities and their stakeholders are affected by and adjust to CDS coverage. We also offer novel insights into the role of non-GAAP earnings in a firm's financial reporting toolset. ${ }^{1}$

CDS coverage has received significant attention due to its conjectured effect on the reference firm's operating, investing, and financing activities, as well as its reporting choices. A common argument in these analyses is that CDS coverage results in a decline in lender monitoring. Formalizing the effect as an "empty creditor problem," Bolton and Oehmke [2011] demonstrate analytically that, in equilibrium, lenders over-insure against credit losses. This, in turn, deteriorates the lenders' incentives to monitor the CDS-covered borrower, removing an important component of the reference firm's oversight structure. Consistent with this notion, empirical research links the initiation of CDS coverage to less conservative financial reporting, higher risk-taking, and greater technological innovation (Chang et al. [2019], Martin and Roychowdhury [2015], Saretto and Tookes [2013], among others).

\footnotetext{
${ }^{1}$ Non-GAAP reporting is the practice of providing performance metrics deviating from those prescribed by the respective domicile's generally accepted accounting principles (we focus on U.S. firms, hence U.S. GAAP). Focusing on earnings, the two most-frequently discussed types are non-GAAP earnings provided by sell-side equity analysts, typically labeled Street, and non-GAAP earnings disclosed by the reporting firm, typically labeled pro forma. In this study, we equate "non-GAAP reporting" and "non-GAAP disclosure" to pro forma earnings.
} 
Unlike entering debt and equity markets, the reference firm does not initiate CDS trading. Thus, CDS coverage forces managers of the reference firms to respond to, rather than design a strategy in anticipation of, a (potential) decline in lender monitoring. ${ }^{2}$ Although weaker monitoring by debt holders may allow reference firm managers additional flexibility to engage in activities that increase shareholder value, the perceived amplification of the agency problem between management and equity investors may outweigh the resultant benefit. A potential approach to managing the challenge is voluntary disclosure. Indeed, in a recent study, Kim et al. [2018] argue that reference firms increase the intensity of forward-looking earnings guidance after the initiation of CDS coverage.

Intensity and quality, however, are distinct characteristics of voluntary disclosure. For example, several studies indicate that the enactment of SEC Regulation G (i.e., Reg G) led to a (temporary) decrease in the frequency of non-GAAP reporting, yet the quality of the metric did not unequivocally improve or deteriorate (e.g., Heflin and Hsu [2008], Kolev et al. [2008]). As another example, Christensen et al. [2019] study non-GAAP reporting after debt covenant violations, documenting that although the likelihood of disclosure decreases, the quality of the disclosed non-GAAP measures improves. As such, our study adds dimensionality to the issue analyzed in Kim et al. [2018], providing a more comprehensive understanding of the change in firms' voluntary disclosure practices around (perceived) monitoring changes induced by CDS coverage.

\footnotetext{
${ }^{2}$ If the reference firms do not initiate trades in CDS markets, natural questions become: 1) Are reference firms aware of CDS coverage of their firms; and, 2) If unaware of CDS coverage, why would covered firms change their reporting behavior? We note that the proliferation of financial data sources and interaction between reference firms and lenders, who are among the main players in the CDS market, imply coverage awareness. Moreover, even if these interactions do not take place, changes in the behavior and information needs of informed stakeholders in response to CDS coverage will influence the actions of reference firms.
} 
We focus on manager-reported non-GAAP earnings to analyze the effect of CDS coverage on reference firms' voluntary disclosure quality for several reasons. First, credit markets are a key source of capital for firms, and non-GAAP disclosure plays a fundamental role in facilitating borrowers' access to credit. Anecdotal evidence and research both suggest that the information needs of equity and debt investors differ and that credit events affect the characteristics of nonGAAP earnings (Batta and Muslu [2017], Christensen et al. [2019], Dyreng et al. [2017], Kraft [2015], Thielemann et al. [2019]). Second, reporting non-GAAP earnings has become the norm, rather than the exception (Black et al. [2020]). As such, understanding the effect of CDS coverage on the quality of this popular voluntary disclosure mechanism is informative to a wide audience. Third, assessing the quality of non-GAAP earnings is relatively straightforward, with a wellaccepted set of methodologies in place. ${ }^{3}$ Moreover, relative to other voluntary disclosure tools, non-GAAP earnings disclosure is low-cost for both preparers and users. Finally, relative to other disclosure mechanisms that focus on many pieces of information (i.e., conference calls), nonGAAP earnings reflect the managers' voluntary disclosure strategy with respect to realized earnings. As such, examining the role of non-GAAP reporting in the firms' communication toolbox and statement users' information set offers an informative contribution to the debate on the effects of CDS coverage.

Although non-GAAP earnings are ubiquitous and have received a lot of attention from practitioners, regulators, and researchers, their role in financial reporting remains a contentious issue. Proponents argue that, compared to GAAP earnings, non-GAAP earnings are more value-

\footnotetext{
${ }^{3}$ As we note throughout the study, we follow extant non-GAAP research and assess the quality of the earnings metric via the association of excluded income components with future performance measures. We adopt this approach drawing on the premise that non-GAAP exclusions are transitory (i.e., they should not be associated with future performance). Although extant research proposes alternative measures of non-GAAP quality and considers measures of quality for conference calls and managerial guidance, we favor the persistence measure of non-GAAP quality due to its wide acceptance and validation across settings.
} 
relevant, more predictive of future performance, and do not significantly impair earnings consistency and comparability, on average (Bhattacharya et al. [2003], Black et al. [2020], Bradshaw and Sloan [2002]). Consistent with this view, firms frequently supplement their financial reports with non-GAAP metrics (Black et al. [2020]), both equity and credit analysts adjust GAAP metrics in assessing firm performance (e.g., Batta and Muslu [2017], Gu and Chen [2004]), and accounting standard setters have noted non-GAAP earnings could be a laboratory for improving current GAAP (Black et al. [2019], Golden [2017], Hoogervorst [2015]).

Opponents to non-GAAP disclosure suggest that the lack of standardization of non-GAAP metrics renders them a convenient tool to manage financial statement users' perceptions of the firm, obfuscate true performance, and commingle the effect of core and non-core transactions. Supporting this viewpoint, findings indicate that non-GAAP exclusions are associated with subsequent fundamental and market under-performance, resonating the concern that managers exclude recurring items from non-GAAP earnings opportunistically to meet financial reporting targets (Black and Christensen [2009], Doyle et al. [2003], [2013]). ${ }^{4}$ Importantly, this concern is shared by many regulators who have taken steps to make non-GAAP metrics more transparent (e.g., Michaels and Rapoport [2016], Reg G, and subsequent SEC regulatory guidance). ${ }^{5}$

We believe an analysis of the quality of non-GAAP earnings conditional on CDS coverage speaks directly to the above-mentioned controversy by offering an insight into the effect of a (perceived) change in stakeholder oversight on firms' non-GAAP reporting quality. Moreover, credit market participants are sophisticated and asymmetrically sensitive to downside risk,

\footnotetext{
${ }^{4}$ Notably, evidence also indicates non-GAAP earnings are less conditionally conservative than GAAP earnings, raising the possibility the two metrics co-exist as a compromise between the valuation and stewardship roles of earnings (Heflin et al. [2015], Ribeiro et al. [2019]).

${ }^{5}$ See https://www.sec.gov/rules/final/33-8176.htm and https://www.sec.gov/divisions/corpfin/guidance/nongaapinterp.htm.
} 
rendering them less likely to be affected by non-fundamental factors. Stated differently, this setting is less likely to suffer from contamination by incentive and horizon problems inherent in equity market studies, potentially offering clearer inferences. Thus, evidence on how CDS markets influence non-GAAP earnings adds important insights into non-GAAP disclosure practices.

We conduct our analysis using quarterly data for a sample of U.S. firms for the period March 28, 2003 through the end of fiscal 2015. We start the sample in March 2003 to post-date Reg G, as evidence suggests its enactment changed non-GAAP disclosure practices (Heflin and Hsu [2008], Kolev et al. [2008]). We end the analysis with fiscal 2015 to accommodate data needs for the non-GAAP quality tests. Critical to our examination are management-reported non-GAAP earnings data; we obtain them from the source described by Bentley et al. [2018]. ${ }^{6}$

We follow extant research and operationalize disclosure quality via the association between non-GAAP exclusions and future performance metrics - a weaker association implies higher nonGAAP exclusion quality (Black et al. [2019], [2020], Doyle et al. [2003], Kolev et al. [2008]). Using this framework, we find that the persistence (quality) of non-GAAP exclusions among firms with CDS coverage is lower (higher) than among firms without CDS coverage. This result manifests for both future operating earnings and operating cash flows, is robust to alternative aggregation windows of the performance metrics, and extends beyond the period immediately following the initiation of CDS coverage. The findings also manifest when we conduct the analysis in a difference-in-difference setting using an entropy-balanced sample. As an additional attempt to rule out endogeneity, we consider a cross-sectional analysis using investment grade rating as the cutoff (e.g., Martin and Roychowdhury [2015]). Consistent with expectations, the main result

\footnotetext{
${ }^{6}$ We download the data from https://sites.google.com/view/kurthgee/data. We thank the authors for sharing the dataset.
} 
is driven by non-investment-grade firms, firms for which monitors may be less likely to demand conservatism from published financial reports (Martin and Roychowdhury [2015]).

Our study relates closely to Kim et al. [2018] who find that the frequency of managerial earnings guidance, another popular voluntary disclosure mechanism, increases after the initiation of CDS coverage. Building on their research, and as an exploratory analysis, we also consider the effect of CDS coverage on the likelihood of non-GAAP reporting. As a calibration exercise, we examine the incidence of managerial earnings forecasts in our sample, finding some evidence that, consistent with Kim et al. [2018], this incidence is larger for CDS-covered firms. Turning to nonGAAP earnings, however, we find that the frequency of disclosure is generally lower among firms with CDS coverage. Although exploratory in nature, this result underscores the multifaceted nature of voluntary disclosure, opening the door to future research on the complementarity and substitutability among the disclosure tools at the reference firms' disposal.

In summary, we contribute novel evidence on the response of firms to (perceived) changes in monitoring, focusing on the interplay between CDS coverage and voluntary disclosure. Specifically, we examine non-GAAP earnings disclosure, offering one of the first examinations of the effect of credit markets on this widespread reporting practice. Importantly, we examine the effect of CDS coverage on the quality of voluntary disclosure, adding an important dimension to extant research that focuses on its incidence (Kim et al. [2018]).

Our analyses inform the active debate on the impact of CDS coverage, highlighting a positive effect on a prominent voluntary reporting practice in a sea of negative externalities. Our findings also inform accounting standard setters and securities regulators in their evaluation of the role of non-GAAP earnings in financial reporting in the pursuit of establishing standards, rules, 
and oversight mechanisms that encourage firm to provide decision-useful "information to help investors, creditors, and others" (FASB [2008], CON1-11, paragraph 37).

\section{Background and Hypothesis Development}

\subsection{NON-GAAP EARNINGS DISCLOSURE}

The disclosure of non-GAAP earnings is widespread and continues to rise in popularity (e.g., Black et al. [2020], Brown et al. [2020]). Proponents of the practice often reference the need to provide financial performance metrics that are more informative to financial statement users than GAAP measures. Consistent with this notion, evidence indicates non-GAAP earnings have better predictive power for future fundamental and market performance than GAAP earnings, and financial statement users take note (Bhattacharya et al. [2003], Bradshaw and Sloan [2002]). As examples, non-GAAP earnings have become the financial reporting target of choice for equity markets (e.g., Brown and Caylor [2005]), compensation contracts often benchmark performance against non-GAAP earnings (Curtis et al. [2018], Gaver and Gaver [1998], Potepa [2020]), and credit markets frequently evaluate firm performance on a non-GAAP basis (Dyreng et al. [2017], Kraft [2015]). The prominence of non-GAAP earnings, however, renders them a convenient tool to manage financial statement users' perceptions of the firm. Among many examples, evidence suggests that some of the exclusions applied to GAAP earnings to arrive at non-GAAP earnings

are persistent, value-relevant, and risk-relevant (Doyle et al. [2003], Heflin et al. [2018]). Moreover, findings indicate firm managers exercise judgement in defining non-GAAP earnings to guide the analysts' consensus definition of earnings and to beat the analysts' consensus forecast (e.g., Bentley et al. [2018], Doyle et al. [2013]). 
Extant research on non-GAAP earnings disclosure primarily focuses on equity markets. This is not surprising considering equity analysts often forecast earnings on a non-GAAP basis, and, over the past two decades, investors have shifted focus to the analysts' consensus forecast to gauge firm performance. Evidence suggests sell-side analysts discipline non-GAAP reporting, reversing the lowest quality adjustments applied by firm management (Bentley et al. [2018], Gu and Chen [2004]). Research, however, also suggests analysts sometimes adopt lower quality adjustments, integrating them into their assessment of non-GAAP earnings. For example, Bentley et al. [2018] demonstrate managers influence what analysts include in and exclude from their nonGAAP estimates, and a growing body of research suggests managers mask recurring expenses as one-time items to beat the analysts' consensus earnings forecast (e.g., Cain et al. [2020], McVay [2006]).

Research linking non-GAAP disclosure and credit markets is notably more limited in scale and scope. Although findings imply credit markets also apply adjustments to GAAP measures, these adjustments often differ from the adjustments considered by equity markets. Using credit analysts as an example, evidence suggests their adjustments emphasize downside risk. As a case in point, Kraft [2015] notes that Moody's credit analysts adjust GAAP financial results with a focus on default risk. Focusing specifically on earnings, Batta and Muslu [2017] similarly document that among riskier firms, the adjustments applied by credit rating analysts result in lower earnings than the adjustments applied by sell-side equity analysts.

To summarize, extant evidence indicates non-GAAP earnings improve upon the informativeness of GAAP earnings, on average. The prominence of the metric, however, makes it a prime target for opportunistic reporting. Collectively, current findings offer support for both the 
informative and opportunistic use of non-GAAP earnings disclosure, as the debate on which effect dominates remains active.

\subsection{CREDIT DEFAULT SWAPS}

Single-name credit default swaps are contracts that insure the buyer against pre-specified credit events related to the underlying security. In exchange, the seller receives a periodic fee proportional to the notional value of the security, typically quoted as a spread. ${ }^{7}$ Since their introduction in the early 1990's, CDS contracts have grown in popularity, giving rise to a multitrillion dollar market. This market does not encompass all U.S. firms; however, it covers a large portion of the investable universe of U.S. publicly traded firms by market capitalization. CDS are standardized and significantly more liquid than corporate public debt, rendering the CDS market a convenient setting to study credit-related phenomena (Callen et al. [2009]). ${ }^{8}$

Prior research examines the effect of the initiation of CDS coverage on the business and reporting practices of the referenced entity (i.e., the "covered firm"). Many of these studies use the "empty creditor" model of Bolton and Oehmke [2011] to argue that when CDS contracts are available, creditors over-insure. As a result, creditors decrease their monitoring effort, allowing the borrower to change its financing and reporting behavior. As examples, extant studies in this area link the initiation of CDS coverage to higher leverage (Saretto and Tookes [2013]) and lower financial reporting conservatism (Martin and Roychowdhury [2015]).

Unlike equity or debt issuance, in the case of CDS, the reference firm typically does not initiate coverage. As such, it must manage the externalities of CDS coverage. For example, considering the perception of reduced monitoring by lenders, financial statement users likely

\footnotetext{
${ }^{7}$ For example, if the annualized payment for a CDS contract with a notional value of $\$ 100$ million were $\$ 1.6$ million, the spread would be 160 basis points.

${ }^{8}$ Augustin et al. [2014], among others, provide a detailed discussion of CDS.
} 
demand additional information about the reference firm, forcing management to reconsider its approach to financial reporting and disclosure. Consistent with this notion, Kim et al. [2018] argue firms newly covered by CDS increase the level of voluntary disclosure, indicated by more frequent management earnings guidance.

In addition, a growing body of research suggests CDS markets are sensitive to accounting information. Callen et al. [2009] document CDS spreads are sensitive to earnings news. Specifically, the authors find that among reference firms, the change in CDS spread around the earnings announcement date is associated with both the cash flow and accrual components of earnings, as well as with the earnings surprise relative to the analysts' consensus forecast. Moreover, evidence suggests CDS markets incorporate private information in pricing CDS contracts (Acharya and Johnson [2007]) and not only anticipate earnings innovations, but also process them more efficiently than equity markets (e.g., Zhang and Zhang [2013]). Finally, findings indicate CDS markets are sensitive to the quality of accounting reports (Arora et al. [2014], Bhat et al. [2016], Ertan et al. [2018]).

Collectively, extant research supports the notion that CDS coverage affects the reference firms' real activities and reporting practices and suggests CDS markets are sophisticated and sensitive to accounting information.

\subsection{HYPOTHESIS DEVELOPMENT}

CDS coverage has attracted broad attention due to, among other reasons, its purported externalities. As noted earlier, as CDS contracts become available, lenders' incentives to monitor the respective borrower may decrease, leading to a shift in firms' real operations and financial reporting behavior (Bolton and Oehmke [2011], Kim et al. [2018], Martin and Roychowdhury [2015], Saretto and Tookes [2013]). Building on this stream of research, we hypothesize that CDS 
coverage is plausibly associated with a firm's non-GAAP disclosure. This effect is non-trivial, as non-GAAP earnings disclosure has become the norm, rather than the exception, over the past few years (Black et al. [2020]), making it a key component of the public firms' disclosure toolset.

To underscore the point, non-GAAP reporting is ubiquitous, attracting the attention of regulators, financial statement users, and the media. As we note earlier, an often-cited argument for reporting non-GAAP earnings is that GAAP do not accommodate specific, one-off, transactions of individual companies or sufficiently address the divergent needs of varied financial statement users. Recent research supports this intuition. As examples, Heflin et al. [2015] find nonGAAP exclusions remove the conditionally conservative component of GAAP income; and, Ribeiro et al. [2019] contrast the characteristics of GAAP and non-GAAP earnings, linking the wedge between these metrics to the stewardship and valuation roles of financial reporting.

Although managerial guidance and conference calls, among others, are instrumental to a firm's voluntary disclosure tactics and strategy, non-GAAP earnings are an attractive setting to analyze our research question, as they allow for an intuitive assessment of reporting quality and are relatively low-cost to prepare and easy-to-read and understand for users. Stated differently, we expect an examination of the interplay between CDS coverage and non-GAAP earnings disclosure to offer insights that cannot be gleaned from other settings, such as managerial guidance or conference calls. Moreover, whereas prior research focuses on the frequency of voluntary disclosure (Kim et al. [2018]), studying non-GAAP earnings allows a direct assessment of quality. In other words, our analysis offers important insights into the interplay between the quality of voluntary disclosure and CDS coverage, supplementing our understanding of the role of CDS coverage, and, more generally, shifts in creditor monitoring, in shaping the information environment of the firm. 
At the implementation level, we assess whether the quality of non-GAAP earnings differs between firms with and without CDS coverage by testing whether the predictive power of nonGAAP exclusions for future financial performance changes after the initiation of CDS coverage. The question of whether or not the quality of non-GAAP earnings changes after a firm is covered by CDS faces significant ex ante tension. Specifically, the empty creditor problem, formalized by Bolton and Oehmke [2011] and referenced by related research, suggests lenders reduce their monitoring of the reference firm after CDS coverage initiation. This intuition, in turn, points to: 1) An overall weakening in disclosure quality; and, 2) A shift of GAAP earnings to cater more to the valuation role of accounting, resulting in lower need for supplemental non-GAAP disclosure to provide value-relevant earnings-related information. ${ }^{9}$ Stated differently, this mechanism implies a potential deterioration in the quality of non-GAAP disclosure in the presence of CDS coverage. If stakeholders recognize the (potential) deterioration in lender monitoring of CDS-covered firms, however, they may demand better supplemental disclosure, yielding higher quality non-GAAP earnings. Mindful of this tension, we state our hypothesis in null form:

Hypothesis 1: The quality of non-GAAP exclusions does not differ between firms with and without CDS coverage.

\section{Sample Selection and Descriptive Statistics}

\subsection{SAMPLE SELECTION}

To conduct the analysis, we require data on manager-reported non-GAAP earnings and CDS coverage. We obtain them from the non-GAAP earnings dataset described in Bentley et al.

\footnotetext{
${ }^{9}$ Indeed, Heflin et al. [2015] document that the exclusions made to calculate non-GAAP earnings attenuate the conditional conservatism in GAAP earnings, and Martin and Roychowdhury [2015] argue GAAP earnings become less conservative after the initiation of CDS coverage.
} 
[2018] and the Markit CDS dataset, respectively. Markit provides pricing on single-name CDS contracts from a consortium of CDS sellers. We follow prior research and focus on five-year contracts on senior unsecured debt with modified restructuring clauses (Callen et al. [2009], Kim et al. [2018], Markit [2009], [2012]). We acquire financial data from Compustat and equity market data from CRSP.

We summarize the sample selection procedure in Table 1, Panel A. We start with the Compustat universe for fiscal years 2003 through 2015 with earnings announcement dates on or after March 28, 2003 (the effective date of Reg G), yielding 272,821 firm-quarter observations. From this pool, we remove real estate investment trusts, as they report a standardized non-GAAP earnings metric (funds from operations). We also eliminate observations with negative book value of equity or price per share below $\$ 1$, as well as firm-quarters not covered by the Bentley et al. [2018] dataset or with missing data for the main regression variables (we define all variables in Appendix A). This yields a sample of 41,424 firm-quarter observations with firm-reported nonGAAP earnings. ${ }^{10}$

An important feature of the sample is that all observations post-date the enactment of Reg G. That is, the firms we examine are required to reconcile the reported non-GAAP metrics to the closest comparable GAAP measure, making it easier for statement users to assess the information content of non-GAAP earnings and non-GAAP exclusions. Moreover, because the CDS data, as provided by Markit, are available prior to 2003, our identification of CDS coverage initiation is less likely to be affected by measurement error arising from coverage in periods pre-dating the

\footnotetext{
${ }^{10}$ Except for EPS-based measures (i.e., $N G$ and $E X C L$ ), we winsorize all continuous variables at the top and bottom one percent for each year-quarter to attenuate the influence of outlying observations. We do not winsorize $N G$ and EXCL because we expect GAAP earnings, via the reconciliation requirement of Reg $\mathrm{G}$, to provide a reasonableness check on non-GAAP earnings. In untabulated analysis, we verify that winsorizing all continuous variables, including $N G$ and $E X C L$, at the top and bottom one percent for each year-quarter does not affect our main conclusions from Table 3.
} 
dataset. ${ }^{11}$ We summarize the CDS coverage initiations in our sample by fiscal year in Table 1 , Panel B.

\subsection{DESCRIPTIVE STATISTICS}

We present descriptive statistics for our main regression variables in Table 2. On average, non-GAAP earnings $(N G)$ in the sample are positive (0.014), and non-GAAP exclusions (the difference between GAAP earnings including extraordinary items and non-GAAP earnings, $E X C L)$ are negative (-0.010), confirming firms typically exclude expenses when defining nonGAAP earnings. Approximately 20.6 percent of the observations are for firms-quarters with CDS coverage $(T R E A T \times P O S T=1)$, and 22.3 percent of the observations pertain to firms that have CDS coverage at some point during our sample period. ${ }^{12}$

\section{Research Design and Results}

\subsection{CDS COVERAGE AND NON-GAAP EXCLUSION QUALITY}

Our research question focuses on the effect of CDS coverage on the quality of non-GAAP earnings. Following prior research, we operationalize the analysis via the persistence of nonGAAP exclusions, which is a commonly used approach to assessing the quality of non-GAAP reporting (Doyle et al. [2003], Gu and Chen [2004], Kolev et al. [2008]). The test builds on the observation that high quality non-GAAP reporting implies the respective exclusions from GAAP earnings are non-recurring. Stated differently, if non-GAAP exclusions are lower quality, they

\footnotetext{
${ }^{11}$ We identify the initiation of CDS coverage as the first reported spread on a five-year maturity contract in Markit. ${ }^{12}$ Untabulated analyses indicate CDS initiations are concentrated in the period 2001 through 2005, and the number of CDS-covered firms peaks in 2008. Because our sample period begins in March 2003 to post-date Reg G, the proportion of the observations for CDS firms before coverage is low (i.e., most CDS firms have CDS coverage throughout the sample period). To alleviate identification concerns, we also consider a sample excluding firms with CDS coverage throughout the sample period, as well as a difference-in-differences estimator with entropy balancing. We discuss related findings in later sections.
} 
would be more persistent and more predictive of future cash flows and earnings. We empirically capture non-GAAP exclusion persistence by estimating the following model:

$$
\begin{array}{rl}
F O=\beta_{0}+\beta_{1} & N G+\beta_{2} N G \times T R E A T \times P O S T+\beta_{3} E X C L+\beta_{4} E X C L \times T R E A T \times P O S T \\
& +\beta_{5} T R E A T \times P O S T+\beta_{6} R A T E D+\beta_{7} I N V G R D+\beta_{8} L E V+\beta_{9} M T B \\
& +\beta_{10} M A R G I N_{t-1}+\beta_{11} S I Z E+\beta_{12} S D \_R E T+\beta_{13} S A L G R W \\
& +\beta_{14} R O A_{t-1}+\sum F E+\varepsilon
\end{array}
$$

where $F O$ is set to either future operating cash flows or future operating income, defined as the sum of cash flows from operations or operating income after depreciation and amortization over the four, eight, or twelve quarters following the treatment quarter. $N G$ and $E X C L$ are non-GAAP earnings and exclusions, respectively. All four variables are scaled by total assets at the beginning of the treatment quarter. The vector of controls follows prior research, including measures of size, profitability, and risk (Black et al. [2020], Doyle et al. [2003], Kolev et al. [2008]). We also estimate a benchmark model with $N G, E X C L$, and both industry and year-quarter fixed effects as independent variables. We estimate equation (1) using OLS regressions with standard errors clustered by firm.

The estimated coefficients $\beta_{1}$ and $\beta_{3}$ in equation (1) reflect the change in future operating performance for a dollar change in non-GAAP earnings and exclusions, respectively. Thus, if $N G$ (EXCL) are fully persistent (transient), $\beta_{1}$ should be positive and close to four ( $\beta_{3}$ should be zero) in the one-year-ahead specification (e.g., Doyle et al. [2003]). We are interested in the effect of CDS coverage on the quality of non-GAAP reporting. As such, our focus is on $\beta_{4}$, which captures the differential persistence of non-GAAP exclusions conditional on a firm having CDS coverage. A significantly negative (positive) $\beta_{4}$ is consistent with an improvement (deterioration) in the quality of the firm's voluntary disclosure after the initiation of CDS coverage.

We present the results from estimating equation (1) in Table 3. Starting with one-yearahead financial performance, we tabulate the estimates from the operating cash flows (operating 
income after depreciation and amortization) specifications in Panel A (Panel B). Consistent with prior research, we document a significantly positive association between non-GAAP earnings $(N G)$ and future financial performance in each of the examined specifications. The estimated coefficients on EXCL, however, are also significantly positive, consistent with extant evidence non-GAAP exclusions are not strictly transitory. Consistent with the notion managers exclude GAAP earnings components that are relatively more transitory when constructing non-GAAP earnings, however, we note that the estimated coefficients on EXCL are significantly smaller than these on $N G$ across specifications (untabulated). Collectively, the baseline findings mirror extant evidence on non-GAAP disclosure (e.g., Doyle et al. [2003], Gu and Chen [2004], Kolev et al. [2008]), offering additional confidence that sample selection is not a likely driver for the results we document.

Turning to the formal test of $\mathrm{H} 1$, we examine the effect of CDS coverage on non-GAAP exclusion quality in columns 2 and 4, focusing on future operating cash flows in Panel A and future operating income in Panel B. The estimated coefficients on EXCL $\times T R E A T \times P O S T$ are significantly negative, indicating less persistent non-GAAP exclusions, and higher quality nonGAAP disclosure, among CDS-covered firms. This finding is consistent with management responding to external users' perceived demand for higher-quality voluntary disclosure as a substitute for the (potentially) weakened monitoring by creditors. The result manifests both in the baseline specifications and in the models with control variables. To underscore the point, in two of the four specifications in Panels A and B testing H1 (models (2) and (4)), the estimated coefficients imply that non-GAAP exclusions are not associated with future operating cash flows and operating income after the initiation of CDS coverage. ${ }^{13}$ As validation, we also note that in the

\footnotetext{
${ }^{13}$ We note that in column 4 of Panel A, the estimated coefficients suggest the total effect of post-CDS-coverage exclusions $(E X C L+E X C L \times T R E A T \times P O S T)$ is significantly negative. We observe similar patterns in columns 1 and
} 
models with controls, the estimated coefficients on the control variables are generally consistent with prior research. For example, we note that firm size and the market-to-book ratio are positively associated with future operating cash flows and earnings, whereas the estimated coefficients on sales growth are negative (Doyle et al. [2003], Kolev et al. [2008]).

To address the possibility that the mix of non-GAAP exclusions post-CDS coverage shifts to items affecting the reference firms' financial performance in the longer term, we re-estimate equation (1), aggregating operating cash flows and operating income over the next two years (eight quarters) and three years (twelve quarters). Turning to Panel $\mathrm{C}$ of Table 3 , we note that the inferences are robust to this research design modification. Specifically, the estimated coefficients on $N G$ and EXCL are significantly positive, with the latter much smaller than the former, confirming that although non-GAAP exclusions focus on the more transitory income components, they are not fully transitory. The estimated coefficients on EXCL $\times T R E A T \times P O S T$ similarly remain significantly negative across specifications, implying firms with CDS coverage provide higher quality non-GAAP disclosure. Our conclusions are unchanged when we estimate the models using operating cash flows and operating income for years $t+2$ and $t+3$ separately as dependent variables (results untabulated).

Collectively, the results in Table 3 point to a positive link between CDS coverage and the quality of a firm's non-GAAP earnings disclosure, supporting rejection of $\mathrm{H} 1$.

\subsection{CDS COVERAGE INITIATION AND NON-GAAP EXCLUSION QUALITY}

CDS markets pre-date our non-GAAP earnings data. Hence, it is possible that some firms in our sample are classified as "CDS-covered" (i.e., TREAT $\times P O S T=1$ ) throughout the entire

2 of Panel C. Possible explanations for the negative total effects include accrual reversals and mean reversion of the non-GAAP exclusions. A comprehensive analysis of the issue is beyond the scope of this study; hence, we relegate it to future research. 
sample period. This characteristic of the sample raises the question of whether the results in Table 3 may be affected by systematic differences that persist throughout the sample period for firms with long-standing CDS coverage relative to firms for which: 1) CDS coverage is initiated during the sample period; or, 2) CDS coverage is never initiated. To address this concern, we repeat the analyses in Table 3, Panels A and B, using a sample that excludes firms with CDS coverage throughout the entire sample period. This research design refinement allows for a more direct comparison of firms that experience CDS coverage initiation during the sample period with those that do not.

We present these results in column 1 of Table 4, Panels A and B. Like the full-sample analyses, the estimated coefficients on $E X C L \times T R E A T \times P O S T$ are significantly negative in both the future operating cash flows and operating income specifications. In fact, these estimated coefficients in the restricted sample are numerically larger in absolute value than those in the full sample. Stated differently, we continue to find evidence CDS coverage is associated with higher quality non-GAAP earnings disclosure. This observation suggests that our inferences are not a byproduct of the structure of the sample we use for our main analysis.

\subsection{CDS COVERAGE AND NON-GAAP EXCLUSION QUALITY: EFFECT DURATION}

In the main analysis, we pool all observations with CDS coverage. It is possible, however, that the effect attenuates as financial statement preparers and users become comfortable with the new equilibrium resulting from the initiation of CDS coverage for the firm. ${ }^{14}$ Alternatively, it is possible that financial statement preparers and users gradually adjust to the effects of CDS coverage over time. Because the estimated coefficient on EXCL $\times T R E A T \times P O S T$ captures the

\footnotetext{
${ }^{14}$ For example, extant research finds that the enactment of Reg $\mathrm{G}$ resulted in a decline in the frequency of non-GAAP reporting, but the effect was short-lived (e.g., Bentley et al. [2018], Black et al. [2012], Black et al. [2020], Heflin and Hsu [2008]).
} 
average post-adoption effect, the research design we deploy thus far does not speak to either of these scenarios, potentially obscuring interesting dynamics in the examined relationship.

To gain insights into how quickly the quality of non-GAAP exclusions improves after the initiation of CDS coverage and how long the effect persists, we modify equation (1) by replacing the TREAT $\times P O S T$ variable with indicators set to one for each quarter at least one year $(F 1 Y)$, two years $(F 2 Y)$, or three years $(F 3 Y)$ after the CDS coverage initiation, respectively, for each reference firm; zero otherwise. Thus, the estimated coefficient on $E X C L \times F 1 Y$ captures the effect of CDS coverage initiation on non-GAAP exclusion persistence for firm-quarter observations for which CDS coverage occurred at least one year prior to the quarter for which non-GAAP earnings is disclosed. This research design allows us to understand whether the results from the analyses to this point are temporary, driven by the period immediately following the initiation of CDS coverage, or reflect a long term change in the reporting practices of the reference firms. Similar to the analysis described in the preceding section, we focus on the sample that excludes firms with CDS coverage during the entire sample period.

We present the regression results in Table 4, Panels A and B, columns 2 through 4. The estimated coefficients on the variables of interest $-E X C L \times F 1 Y, E X C L \times F 2 Y$, and $E X C L \times F 3 Y-$ are significantly negative in both the future operating cash flows and operating earnings specifications. Thus, our results suggest the change in quality of non-GAAP reporting associated with the initiation of CDS coverage is both quick and persistent. ${ }^{15}$

\footnotetext{
${ }^{15}$ In untabulated analysis, we examine the speed of adjustment directly, focusing on the year immediately following the initiation of CDS coverage. Specifically, we replace the $F 1 Y$ variable with an indicator equal to one for each of the four quarters immediately following the CDS coverage initiation of the reference firm; zero otherwise. The estimated coefficient on the interaction of interest is significantly negative for both the operating cash flows and operating income specifications, suggesting the post-CDS-coverage improvement in non-GAAP earnings quality occurs relatively quickly.
} 


\subsection{CROSS-SECTIONAL ANALYSIS}

Our findings so far are consistent with stakeholders recognizing that CDS coverage may affect the quality of GAAP-based financial reports. As a result, managers respond to the information needs of equity investors by providing higher quality non-GAAP earnings disclosure. As we note earlier, a likely channel is weaker creditor monitoring arising from the empty creditor problem (Bolton and Oehmke [2011]). To confirm that higher quality non-GAAP disclosure is driven by managers' reaction to a perceived decrease in creditor monitoring, we further investigate whether the association between CDS coverage and non-GAAP exclusion quality is stronger for firms where the decrease of creditor monitoring after CDS initiation is likely greater.

To this end, we partition the sample relative to whether the firm is considered "investment grade" (Kim et al. [2018], Martin and Roychowdhury [2015]). We consider this partition because we conjecture that the decrease in the level of creditor monitoring after CDS initiation is greater for non-investment-grade firms than for investment-grade firms. We base the conjecture on the observation that creditors likely maintain relatively higher levels of monitoring of non-investmentgrade firms than of investment-grade firms before CDS contracts for the registrant become available. More specifically, compared with creditors of investment-grade firms who frequently refer to the credit ratings provided by credit rating agencies for contracting purposes, creditors of non-investment-grade firms rely more on borrowers' publicly disclosed accounting information in relation to debt covenants. Moreover, monitors of non-investment grade firms appear to demand less accounting conservatism from public accounting reports (Martin and Roychowdhury [2015]), consistent with less demand for less contract-relevant and more value-relevant information. Therefore, in the absence of CDS coverage, creditors of non-investment-grade firms may engage more actively in monitoring the borrowing firms' voluntary disclosure than do creditors of 
investment-grade firms. In addition, since credit rating agencies are less reliant on reference firms' public disclosures to determine credit worthiness due to their access to possible alternative sources of information, their monitoring of firms' voluntary disclosure is less likely to be influenced by the introduction of CDS coverage.

When creditors of non-investment-grade firms self-protect against borrower default risk by purchasing CDS, they may reduce their effort in monitoring the borrowers. As a result, the decrease in creditor monitoring due to CDS initiation may be greater for non-investment-grade firms than for investment-grade firms. If managers respond to the perceived decline in creditor monitoring by improving their voluntary disclosure quality, we expect the improvement in non-GAAP exclusion quality to be greater for non-investment-grade firms than for investment-grade firms after CDS initiation.

We present the results of estimating equation (1) for the investment- and non-investmentgrade subsamples in Table 5. To account for the fact that not all firms have a publicly-available credit rating, we add a control variable for the existence of a credit rating (RATED) for noninvestment-grade firms. Consistent with the above argument, the estimated coefficients on $E X C L \times T R E A T \times P O S T$ are significantly negative for non-investment-grade firms (columns 2 and 4), indicating that non-GAAP exclusion quality improves significantly after these firms receive CDS coverage. The estimated coefficients on $E X C L \times T R E A T \times P O S T$, however, are not significant for investment-grade firms (columns 1 and 3), indicating that improvement of non-GAAP exclusion quality due to CDS initiation is concentrated among non-investment-grade firms. The evidence supports the argument that non-GAAP exclusion quality improves as managers respond to perceived decreases in creditor monitoring. ${ }^{16}$

\footnotetext{
${ }^{16} \mathrm{Kim}$ et al. [2018] find increased disclosure quantity for firms with higher institutional ownership. In untabulated descriptive statistics, we observe higher institutional ownership for five of six institutional ownership metrics for non-
} 


\subsection{ENTROPY BALANCING AND DIFFERENCE-IN-DIFFERENCES DESIGN}

Our analyses so far employ a research design focused on the association between CDS coverage and non-GAAP reporting quality. We adopt this approach to maximize sample size. Such a research design, however, is particularly susceptible to endogeneity. To address endogeneity concerns, we focus on the effect of CDS initiation directly, deploying a difference-in-differences (DID) research design.

A challenge with a DID estimator in our setting is that firms with and without CDS coverage may be materially different. We address the issue using entropy balancing (EB). EB is a data preprocessing method used to eliminate differences in observable covariates across treatment and control groups. Specifically, EB assigns weights to observations such that the covariate distributions of the control group match those of the treatment group on the set of pre-specified moments (Hainmueller [2012], McMullin and Schonberger [2020]). ${ }^{17}$ To implement the methodology, we first identify treatment firms that have experienced CDS coverage initiation during the sample period and have sufficient data for the analysis in at least four of the eight quarters immediately preceding and in at least four of the eight quarters immediately following the CDS coverage initiation quarter. We retain these observations as the treatment group. Since our focus is CDS coverage initiation, we eliminate firms that have CDS coverage throughout the full sample period from this set of analyses. The control group includes firms that do not have CDS

\footnotetext{
investment-grade firms compared to investment-grade firms in our entropy-balanced sample. Thus, the firms for which disclosure quality improves due to CDS coverage appear to share at least one characteristic with firms for which disclosure quantity increases due to CDS coverage: higher institutional ownership.

${ }^{17}$ There are three key advantages of the EB method. First, it provides a high degree of covariate balance involving the first, second, and possibly higher moments of the covariate distributions, and, thus, always improves upon the balance that can be obtained by other conventional preprocessing adjustments. Second, EB retains valuable information in the data, and thereby retains efficiency for the subsequent analyses, by allowing the unit weights to stay as close as possible to the base weights (i.e., equal weights). In this regard, EB provides a generalization of the propensity score weighting approach (Hirano et al. [2003]). Third, the weights that result from EB can be passed to almost any standard estimator for the subsequent estimation of treatment effects (Hainmueller [2012], Hainmueller and Xu [2013]).
} 
coverage at any point during the sample period. These control firms are reweighted applying the EB algorithm to achieve balanced covariate distributions, where we condition the EB reweighting

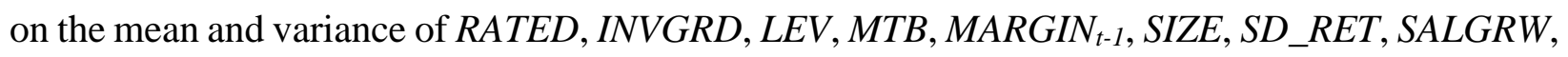
and $R O A_{t-1}$.

A second challenge with implementing the DID estimator in our setting is the staggered initiation of CDS coverage. Specifically, since the treated firms experience the treatment (i.e., CDS coverage initiation) at different points in time, it is not feasible to conduct the experiment focusing on a single year-quarter as a shock, as is commonly done in the literature when the research question pertains to one-shot treatments, such as regulatory interventions. Therefore, instead of implementing the "classic" DID estimator, we include interactions between the non-GAAP earnings components and year-quarter fixed effects, which allows the coefficients of interest to vary by year-quarter (Gipper et al. [2019]). We estimate the following regression model:

$$
\begin{array}{rl}
F O=\beta_{0}+\beta_{1} & N G+\beta_{2} N G \times T R E A T+\beta_{3} N G \times T R E A T \times P O S T+\beta_{4} E X C L \\
& +\beta_{5} E X C L \times T R E A T+\beta_{6} E X C L \times T R E A T \times P O S T+\beta_{7} T R E A T \\
& +\beta_{8} T R E A T \times P O S T+\beta_{9} R A T E D+\beta_{10} I N V G R D+\beta_{11} L E V+\beta_{12} M T B \\
& +\beta_{13} M A R G I N_{t-1}+\beta_{14} S I Z E+\beta_{15} S D \_R E T+\beta_{16} S A L G R W \\
& +\beta_{17} R O A_{t-1}+\sum \beta_{N} N G \times Y e a r-\text { Quarter FE } \\
& +\sum \beta_{N} E X C L \times Y e a r-\text { Quarter FE }+\sum F E+\varepsilon
\end{array}
$$

Similar to equation (1), $F O$ is set to either future operating cash flows or future operating income. Our focus is $\beta_{6}$, which captures the differential persistence of non-GAAP exclusions for a reference firm after the initiation of CDS coverage. As before, we interpret a significantly negative estimated coefficient as evidence of improvement in the quality of non-GAAP reporting. 
Per the evidence in Table 5, we estimate the model separately for investment-grade and noninvestment-grade observations. ${ }^{18}$

We present the results in Table 6. We tabulate the distribution of treatment and control observations by year in Panel A and summarize the covariate mean, variance, and skewness of the treatment and EB-weighted control observations in Panel B. We present the results from estimating equation (2) for investment-grade and non-investment-grade subsamples in Panel C. We document evidence consistent with the argument that non-GAAP exclusion quality improves as managers respond to a perceived decrease in creditor monitoring - the estimated coefficients on $E X C L \times T R E A T \times P O S T$ are significantly negative only for non-investment-grade firms in columns 2 and 4. Moreover, we find some evidence that exclusions are more persistent (i.e., exclusion quality is worse) for investment-grade treatment firms following CDS coverage initiation (column 1). ${ }^{19}$ This effect, however, manifests only in the future operating cash flows specification. Hence, we exercise caution in drawing inferences from this result.

\footnotetext{
${ }^{18}$ We note that the estimated coefficients on $E X C L \times T R E A T \times P O S T$ are negative in all specifications but are not statistically significant at conventional levels ( $t$-statistics range from -1.21 to -1.34) when investment-grade and noninvestment-grade firms are pooled together. This is not surprising considering the lower power of the test in this analysis (we lose 7,665 treatment observations relative to the sample underlying Table 3, Panels A and B) and the evidence that the effect differs for investment- and non-investment-grade firms. Our tests in Table 6, Panel C include 4,611 investment-grade observations (931 treatment, 3,680 control) and 29,148 non-investment-grade observations (633 treatment, 28,515 control).

${ }^{19} \mathrm{We}$ acknowledge the possibility that firms with low-quality non-GAAP earnings disclosure may stop disclosing non-GAAP earnings following CDS coverage initiation, leaving us with a sample of firms that have higher underlying non-GAAP quality, on average. Such a phenomenon is not inconsistent with theoretical arguments that monitors other than lenders increase demand for high-quality information. If some firms choose to cease obfuscating information by removing confusing or misleading non-GAAP disclosures after CDS coverage initiation, information quality may increase in the sample, on average. We weighed a further refinement of our treatment sample to provide more assurance that CDS coverage influences ongoing non-GAAP earnings disclosure and investigate whether the impact of CDS coverage occurs immediately surrounding CDS coverage initiation. The refinement, however, yields disproportionate sampling between treatment and control observations; hence, we do not report results from these robustness checks.
} 


\subsection{FREQUENCY OF NON-GAAP DISCLOSURE AND EARNINGS FORECASTS}

The evidence thus far speaks to the effect of CDS coverage on the persistence of nonGAAP earnings exclusions, a proxy for non-GAAP disclosure quality. Recent research, however, demonstrates a positive association between CDS coverage and the frequency of voluntary disclosure, using management earnings forecasts as an experimental setting (Kim et al. [2018]). In this section, we revisit the result in Kim et al. [2018] and examine the incidence of non-GAAP earnings disclosure as a function of CDS coverage. We do so by estimating the following model:

$$
\begin{aligned}
\text { FREQ }=\beta_{0}+ & \beta_{1} T R E A T \times P O S T+\beta_{2} T R E A T+\beta_{3} R A T E D+\beta_{4} I N V G R D+\beta_{5} L E V \\
& +\beta_{6} M T B+\beta_{7} M A R G I N_{t-1}+\beta_{8} S I Z E+\beta_{9} S D D_{-} R E T+\beta_{10} S A L G R W \\
& +\beta_{11} R O A_{t-1}+\sum F E+\varepsilon
\end{aligned}
$$

where FREQ is either Non-GAAP (an indicator equal to one if the firm discloses non-GAAP earnings during the quarter, zero otherwise) or Number of Forecasts (the natural logarithm of one plus the number of EPS forecasts issued by managers for a given quarter, as reported by IBES). ${ }^{20}$ We estimate the model within the full and entropy-balanced samples. Column 1 and 3 present linear probability model results with Non-GAAP as the dependent variable to accommodate fixed effects (Greene [2004]), interaction terms (Ai et al. [2003]), and entropy-balancing weights, as appropriate. Columns 2 and 4 present OLS regression results with Number of Forecasts as the dependent variable.

We present the results in Table 7. As a calibration exercise (and consistent with Kim et al. [2018]), we find evidence that the number of management earnings forecasts is larger for CDScovered firms in the full sample (column 2). The effect is positive, but turns insignificant, using the entropy-balanced sample (column 4). Turning to non-GAAP earnings, the estimated

\footnotetext{
${ }^{20}$ Our focus in Table 7 is the incidence of non-GAAP earnings disclosure. We include the managerial earnings guidance specifications as a link to Kim et al. [2018].
} 
coefficients on TREAT $\times P O S T$ are negative in both the full (column 1) and entropy-balanced (column 3) samples. Although the coefficient is significant only in the entropy-balanced specification, these results suggest a decrease in the incidence of non-GAAP reporting after the initiation of CDS coverage, offering a counterpoint to the evidence of improvement in quality. ${ }^{21,22}$ To reiterate, this analysis is exploratory in nature. Nevertheless, these results underscore the multifaceted nature of voluntary disclosure, opening the door to future research on the complementarity and substitutability among the disclosure tools at the reference firms' disposal.

\section{Conclusion}

We examine the effect of CDS coverage on the quality of non-GAAP earnings disclosure in a sample of U.S. firm-quarter observations from the post-Regulation-G period. We find that the persistence of non-GAAP exclusions among firms with CDS coverage is, on average, lower than the persistence of non-GAAP exclusions for firms without CDS coverage. The effect manifests across a range of performance measures and measurement windows, is detectable immediately after the initiation of CDS coverage, and is persistent, extending at least three years after the examined shock. In the cross-section, the effect is concentrated in non-investment-grade firms, a subsample where monitors are most likely to have relied on public accounting reports for information in the pre-CDS-coverage regime. These results suggest CDS coverage, which plausibly results in weaker monitoring from creditors, may encourage more intense monitoring from equity investors and result in higher quality voluntary disclosure from CDS-covered firms.

\footnotetext{
${ }^{21}$ In untabulated analysis, we find that the estimated coefficient on TREAT $\times P O S T$ is significantly negative when the model is evaluated with a logit estimator. Such an approach, however, results in the elimination of 23 observations where the industry fixed effects perfectly predict the outcome variable.

${ }^{22}$ When we partition the entropy-balanced sample into investment-grade and non-investment grade firms, we find evidence of lower incidence of non-GAAP earnings disclosure after the initiation of CDS coverage in both subsamples (untabulated).
} 
These findings supplement evidence from prior research that firms increase the quantity of managerial earnings guidance post-CDS-coverage (Kim et al. [2018]).

Our analyses inform the debates on both the impact of CDS coverage and non-GAAP earnings disclosure. Specifically, we offer evidence of a positive effect of CDS coverage on the quality of a firm's voluntary disclosure, complementing extant evidence of decreased accounting conservatism (Martin and Roychowdhury [2015]) and increased incidence of voluntary disclosure (Kim et al. [2018]). More generally, we offer evidence consistent with the notion that managers are: 1) Sensitive to potential adverse effects of CDS coverage on financial reporting quality deriving from perceived changes in monitoring by capital market participants; and, 2) Respond to these potential adverse effects of CDS coverage by improving the quality of voluntary disclosure. Our results, when considered in combination with those from Martin and Roychowdhury [2015] and Kim et al. [2018], suggest that although contracting-relevant information may decline with the (perceived) reduction in lender monitoring resulting from CDS coverage, valuation-relevant information may increase as stakeholders other than lenders increase their demand for decisionuseful information. We believe our findings inform a broad audience, emphasizing an important effect of CDS coverage on managers' disclosure choices. 
APPENDIX A

Variable Definitions

\begin{tabular}{|c|c|}
\hline Variable & Definition \\
\hline$E X C L$ & $\begin{array}{l}\text { Non-GAAP exclusions, calculated by subtracting non-GAAP earnings (NG) from GAAP } \\
\text { earnings, where GAAP earnings is defined as the product of diluted EPS and outstanding } \\
\text { common shares for diluted EPS (Compustat items EPSFIQ } \times \text { CSHFDQ), scaled by total } \\
\text { assets (Compustat item ATQ) for the prior quarter. }\end{array}$ \\
\hline$F 1 Y$ & $\begin{array}{l}\text { Indicator variable equal to one for every quarter at least one year after a firm has a five- } \\
\text { year-maturity CDS spread quote available in the Markit database, zero otherwise. For firms } \\
\text { with a five-year-maturity CDS spread quote available as of Dec. } 31,2002 \text {, the indicator } \\
\text { variable is set to missing. }\end{array}$ \\
\hline$F 2 Y$ & $\begin{array}{l}\text { Indicator variable equal to one for every quarter at least two years after a firm has a five- } \\
\text { year-maturity CDS spread quote available in the Markit database, zero otherwise. For firms } \\
\text { with a five-year-maturity CDS spread quote available as of Dec. 31, 2002, the indicator } \\
\text { variable is set to missing. }\end{array}$ \\
\hline$F 3 Y$ & $\begin{array}{l}\text { Indicator variable equal to one for every quarter at least three years after a firm has a five- } \\
\text { year-maturity CDS spread quote available in the Markit database, zero otherwise. For firms } \\
\text { with a five-year-maturity CDS spread quote available as of Dec. 31, 2002, the indicator } \\
\text { variable is set to missing. }\end{array}$ \\
\hline$F O C F_{t+N}$ & $\begin{array}{l}\text { Future operating cash flows, defined as the summation of cash flows from operations } \\
\text { (Compustat item OANCFY for quarter } 1(\mathrm{Q} 1) \text { and quarterly first difference of OANCFY } \\
\text { for Q2-4) over the four, eight, or twelve quarters following quarter } q(\mathrm{t}+1, \mathrm{t}+2, \mathrm{t}+3) \text {, scaled } \\
\text { by total assets at the end of quarter } q-1 \text {. }\end{array}$ \\
\hline FOIN $_{t+N}$ & $\begin{array}{l}\text { Future operating income, defined as the summation of operating income after depreciation } \\
\text { and amortization (Compustat item OIADPQ) over the four, eight, or twelve quarters } \\
\text { following quarter } q(\mathrm{t}+1, \mathrm{t}+2, \mathrm{t}+3) \text {, scaled by total assets at the end of quarter } q-1 \text {. }\end{array}$ \\
\hline$I N V G R D$ & $\begin{array}{l}\text { Indicator variable equal to one if a firm has a credit rating within the investment grade } \\
\text { category, zero otherwise. Firms with S\&P long-term credit ratings (Compustat item } \\
\text { SPLTICRM) equal to or better than BBB-, or firms with S\&P short-term credit ratings } \\
\text { (Compustat item SPSTICRM) equal to and above A-3, are considered investment-grade. } \\
\text { https://www.standardandpoors.com/en US/web/guest/article/-/view/sourceId/504352. }\end{array}$ \\
\hline$L E V$ & $\begin{array}{l}\text { Leverage, calculated as long-term debt (Compustat item DLTTQ), scaled by the sum of } \\
\text { market value of equity and total liabilities (Compustat items PRCCQ } \times \text { CSHOQ + LTQ). }\end{array}$ \\
\hline
\end{tabular}

Data Source

Compustat,

Bentley et al. [2018]

Markit

Markit

Markit

Compustat

Compustat

Compustat

Compustat 
MARGIN

MTB

$N G$

Non-GAAP

Number of Forecasts

$R O A$

RATED

SALGRW

SIZE

SD_RET

TREAT

TREAT $\times P O S T$
Profit margin, calculated as firm's net income divided by sales (Compustat items IBQ $\div$ SALEQ).

Market-to-book ratio, calculated as firm's market capitalization divided by its common/ordinary equity (Compustat items PRCCQ $\times$ CSHOQ $\div$ CEQQ).

Non-GAAP earnings, defined as the product of non-GAAP EPS (measured to two decimal places) and outstanding common shares for diluted EPS, scaled by total assets in the prior quarter.

Indicator variable equal to one when the firm reports non-GAAP earnings during a specific quarter, and zero otherwise.

The number of management earnings forecasts, calculated as the natural $\log (1+$ the number of EPS forecast issued by managers related to earnings for quarter $q$ ).

Return on assets, calculated as income before extraordinary items (Compustat item IBQ) divided by the total assets in the prior quarter.

Indicator variable equal to one for firm-quarters if either the short- or long-term S\&P credit rating is available, zero otherwise.

Sales growth, calculated as the sales (SALEQ) in the current quarter divided by the sales in the prior quarter.

Firm size, calculated as the natural logarithm of firms' market value of equity.

Equity return volatility, calculated as the standard deviation of raw equity returns (CRSP item RET) over the period from the $2^{\text {nd }}$ day after quarter $q$-1's earnings announcement to the $2^{\text {nd }}$ day before quarter $q$ 's earnings announcement.

Indicator variable equal to one if there is a CDS market for the firm at any point in time during our sample period, zero otherwise.

Indicator variable equal to one for every quarter after which a firm has a five-year-maturity CDS spread quote available in the Markit database, zero otherwise. Note that since our sample period starts from Mar. 28, 2003, for firms with a five-year-maturity CDS spread quote available as of Dec. 31, 2002, the indicator variable equals one for the entire sample period.
Compustat

Compustat

Compustat,

Bentley et al. [2018]

Bentley et al. [2018]

IBES

Compustat

Compustat

Compustat

Compustat

CRSP

Markit

Markit 


\section{REFERENCES}

ACHARYA, V., AND T. Johnson. "Insider Trading in Credit Derivatives." Journal of Financial Economics 84 (2007): 110-141.

Ai, C., AND E. NorTOn. "Interaction Terms in Logit and Probit Models." Economics Letters 80 (2003): 123-129.

ARORA, N., S. Richardson, AND I. TunA. "Asset Reliability and Security Prices: Evidence from Credit Markets.” Review of Accounting Studies 19 (2014): 363-395.

Augustin, P., M. Subrahmanyam, D. Tang, And S. Wang. "Credit Default Swaps: A Survey." Foundations and Trends in Finance 9 (2014): 1-196.

BattA, G., AND V. Muslu. "Credit Rating Agency and Equity Analysts' Adjustments to GAAP Earnings." Contemporary Accounting Research 34 (2017): 783-817.

Bentley, J., T. Christensen, K. Gee, And B. Whipple. 'Disentangling Managers' and Analysts' Non-GAAP Reporting.” Journal of Accounting Research 56 (2018): 1039-1081.

Bhat, G., CALLEN, J. L. AND D. SEGAL. "Testing the Transparency Implications of Mandatory IFRS Adoption: The Spread/Maturity Relation of Credit Default Swaps." Management Science 62 (2016), 3472-3493.

Bhattacharya, N., E. Black, T. Christensen, and C. Larson. "Assessing the Relative Informativeness and Permanence of Pro Forma Earnings and GAAP Operating Earnings." Journal of Accounting and Economics 36 (2003): 285-319.

Black, D., E. Black, T. Christensen, And W. Heninger. "Has the Regulation of Pro Forma Reporting in the US Changed Investors' Perceptions of Pro Forma Earnings Disclosures?" Journal of Business Finance \& Accounting 39 (2012): 876-904.

Black, D., E. Black, T. Christensen, AND K. GeE. "CEO Pay Components and Aggressive NonGAAP Earnings Disclosure," Unpublished paper, University of Nebraska - Lincoln, University of Oklahoma, University of Georgia, and Penn State University, 2019.

Black, D., And T. Christensen. "U.S. Managers' Use of 'Pro Forma' Adjustments to Meet Strategic Earnings Benchmarks.” Journal of Business Finance \& Accounting 36 (2009): 297-326.

Black, D., T. Christensen, J. Ciesielski, And B. WhipPle. "Non-GAAP Earnings: A Consistency and Comparability Crisis?" Unpublished paper, University of Nebraska Lincoln, University of Georgia, and R.G. Associates, 2020. Available at https://papers.ssrn.com/sol3/papers.cfm?abstract_id=2759312.

Bolton, P., AND M. OenMKe. "Credit Default Swaps and the Empty Creditor Problem." Review of Financial Studies 24 (2011): 2617-2655.

Bradshaw, M., AND R. SlOAN. "GAAP versus the Street: An Empirical Assessment of Two Alternative Definitions of Earnings." Journal of Accounting Research 40 (2002): 41-66.

BROwn, L., AND M. CAYLOR. "A Temporal Analysis of Quarterly Earnings Thresholds: Propensities and Valuation Consequences." The Accounting Review 80 (2005): 423-440.

Brown, N., T. Christensen, A. Menini, And T. StefFen. "Non-GAAP Earnings Disclosure and the Valuation of IPOs," Unpublished paper, University of Illinois at Urbana-Champaign, University of Georgia, University of Padova, and Yale University, 2020. Available at https://papers.ssrn.com/sol3/papers.cfm?abstract_id=2803795.

Cain, C., K. Kolev, And S. MCVay. "Detecting Opportunistic Special Items." Management Science 66 (2020): 2099-2119.

CAllen, J. L., Livnat, J., AND D. Segal. "The Impact of Earnings on the Pricing of Credit Default Swaps." The Accounting Review 84 (2009): 1363-1394. 
Chang, X., Y. Chen, S. Wang, K. Zhang, And W. Zhang. "Credit Default Swaps and Corporate Innovation.” Journal of Financial Economics 134 (2019): 474-500.

Christensen, T., H. Pei, S. Pierce, And L. TAN. "Non-GAAP Reporting Following Debt Covenant Violations." Review of Accounting Studies 24 (2019): 629-664.

Curtis, A., V. Li, AND P. PATrick. "The Use of Adjusted Earnings in Performance Evaluation," Unpublished paper, University of Washington, University of Washington - Bothell, and University of Illinois - Chicago, 2018. Available at https://papers.ssrn.com/sol3/papers.cfm?abstract_id=2682652.

Doyle, J., R. Lundholm, and M. Soliman. "The Predictive Value of Expenses Excluded from Pro Forma Earnings." Review of Accounting Studies 8 (2003): 145-174.

Doyle, J., J. Jennings, AND M. Soliman. 'Do Managers Define Non-GAAP Earnings to Meet or Beat Analyst Forecasts? Journal of Accounting and Economics 56 (2013): 40-56.

DYRENG, S., R. VASHISHTHA, AND J. WEBER. "Direct Evidence on the Informational Properties of Earnings in Loan Contracts.” Journal of Accounting Research 55 (2017): 371-406.

ERTAN, A., S. KAROLYI, AND K. KolEV. 2018. “The Information Quality Effect of Accruals-Based Benchmark Beating: Evidence from the CDS Market," Unpublished paper, London Business School, Carnegie Mellon University, and City University of New York, 2018. Available at https://papers.ssrn.com/sol3/papers.cfm?abstract_id=2815022.

FinANCIAL AcCOUNTING StANDARDS BoARD (FASB). Statement of Financial Accounting Concepts No. 1, 2008. Available at https://www.fasb.org/resources/ccurl/816/894/aop_CON1.pdf.

GAVER, J., AND K. GAVER. "The Relation between Nonrecurring Accounting Transactions and CEO Cash Compensation." The Accounting Review 73 (1998): 235-253.

GipPer, B., C. LeuZ, AND M. MAFFetT. "Public Audit Oversight and Reporting Credibility: Evidence from the PCAOB Audit Inspection Regime.” Review of Financial Studies (2019). Available at https://doi.org/10.1093/rfs/hhz149.

GoldEN, R. "Why the FASB Cares about Non-GAAP Performance Measures." From the Chairman's Desk, 2017 Q1. Available at https://www.fasb.org/jsp/FASB/Page/SectionPage\&cid=1176168752402.

GreEnE, W. "The Behaviour of the Maximum Likelihood Estimator of Limited Dependent Variable Models in the Presence of Fixed Effects." The Econometrics Journal 7 (2004): 98119.

Gu, Z., AND T. CHEN. “Analysts' Treatment of Nonrecurring Items in Street Earnings.” Journal of Accounting and Economics 38 (2004): 129-170.

HAINMUELleR, J. "Entropy Balancing for Causal Effects: A Multivariate Reweighting Method to Produce Balanced Samples in Observational Studies." Political Analysis 20 (2012): 25-46.

Hainmueller, J. AND Y. XU. "ebalance: A Stata Package for Entropy Balancing." Journal of Statistical Software 54 (2013): 1-18.

HEFLIN, F. AND C. HsU. "The Impact of the SEC's Regulation of Non-GAAP Disclosures.” Journal of Accounting and Economics 46 (2008): 349-365.

Heflin, F., C. HsU, AND Q. JIN. “Accounting Conservatism and Street Earnings." Review of Accounting Studies 20 (2015): 674-709.

Heflin, F., K. Kolev, AND B. WhIPPlE. "The Risk-relevance of Street Earnings," Unpublished paper, University of Georgia and City University of New York, 2018. Available at https://papers.ssrn.com/sol3/papers.cfm?abstract_id=3222893. 
HiRANO, K., G. IMBENS, AND G. RIDDER. "Efficient Estimation of Average Treatment Effects Using the Estimated Propensity Score. Econometrica 71 (2003): 1161-1189.

Hoogervorst, H. "Mind the Gap (between non-GAAP and GAAP)." IASB Speech, March 31, 2015. Available at http://archive.ifrs.org/Alerts/Conference/Documents/2015/Speech-Hans-Mind-the-Gapspeech-Korea-March-2015.pdf.

Kim, J., P. Shroff, D. Vyas, And R. WitTenberG-Moerman. "Credit default swaps and managers' voluntary disclosure.” Journal of Accounting Research 56 (2018): 953-988.

Kolev, K., C. Marquardt, AND S. MCVAY. "SEC Scrutiny and the Evolution of Non-GAAP Reporting." The Accounting Review 83 (2008): 157-184.

KRAFT, P. "Rating Agency Adjustments to GAAP Financial Statements and Their Effect on Ratings and Credit Spreads." The Accounting Review 90 (2015): 641-674.

MARKIT. The CDS Big Bang: Understanding the Changes to the Global CDS Contract and North American Conventions, 2009. Available at https://wrdswww.wharton.upenn.edu/documents/731/The_CDS_Big_Bang.pdf?_ga=2.47615459.5340 77239.1555447371-71381679.1530034606.

MARKIT. Markit.com User Guide CDS \& Bonds, 2012. Available at https://wrdswww.wharton.upenn.edu/documents/729/Markit_CDS_Bonds_User_Guide.pdf?.ga=2.4 3976033.534077239.1555447371-71381679.1530034606.

MARTIN, X., AND S. ROYCHOWDHURY. "Do Financial Market Developments Influence Accounting Practices? Credit Default Swaps and Borrowers' Reporting Conservatism.” Journal of Accounting and Economics 59 (2015): 80-104.

McMullin, J., AND B. ScHONBERGER. "Entropy-balanced Accruals." Review of Accounting Studies 25 (2020): 84-119.

McVAy, S. E. "Earnings Management Using Classification Shifting: An Examination of Core Earnings and Special Items." The Accounting Review 81 (2006): 501-531.

MiCHAELS, D., AND M. RAPOPORT. 2016. "SEC signals it could curb use of adjusted earnings figures." The Wall Street Journal, March 16, 2016. Available at https://www.wsj.com/articles/sec-scrutinizing-use-of-non-gaap-measures-by-publiccompanies-1458139473?mod=djemCFO_h.

PotePA, J. "The Treatment of Special Items in Calculating CEO Cash Compensation." Review of Accounting Studies (2020). Available at https://doi.org/10.1007/s11142-019-09523-X.

RIBEIRO, A., Y. SHAN, AND S. TAYLOR. "Non-GAAP Earnings and the Earnings Quality Tradeoff. Abacus 55 (2019): 6-41.

SARETTO, A., AND H. ToOKES. "Corporate Leverage, Debt Maturity, and Credit Supply: The Role of Credit Default Swaps." Review of Financial Studies 26 (2013): 1190-1247.

Thielemann, F., T. Dinh, And H. Kang. 2019. "Non-GAAP Reporting and Debt Market Outcomes: Evidence from Regulation G." Schmalenbach Business Review 71 (2019): 169203.

ZhANG, G., AND S. ZHANG. "Information Efficiency of the U.S. Credit Default Swap Market: Evidence from Earnings Surprises.” Journal of Financial Stability 9 (2013): 720-730. 


\section{TABLE 1}

Sample Selection and Characteristics

\begin{tabular}{|c|c|c|c|}
\hline Panel A: Sample selection & Observations & Percentage & No. of firms \\
\hline $\begin{array}{l}\text { Available firm-quarter observations in Compustat from fiscal year } 2003 \text { to } 2015 \text {, with } \\
\text { earnings announcement dates on or after Mar. 28, } 2003 \text { (the enactment date of Reg G) }\end{array}$ & 272,821 & $100 \%$ & 10,045 \\
\hline Less: real estate investment trusts (REITs) & $(10,081)$ & $(4 \%)$ & (235) \\
\hline Less: negative equity or share price less than $\$ 1$ & $(18,207)$ & $(7 \%)$ & $(255)$ \\
\hline Less: not included in Bentley et al. (2018) & $(108,734)$ & $(40 \%)$ & $(2,819)$ \\
\hline Less: missing information for variables required in the main empirical analyses & $(17,227)$ & $(6 \%)$ & (666) \\
\hline Total firm-quarters with and without non-GAAP earnings disclosure & 118,572 & $43 \%$ & 6,070 \\
\hline Firm-quarters with non-GAAP earnings disclosure & 41,424 & $15 \%$ & 4,092 \\
\hline
\end{tabular}

\begin{tabular}{|c|c|c|c|}
\hline \multicolumn{4}{|c|}{ Panel B: CDS initiations by fiscal year } \\
\hline Year & Total CDS-covered firms & CDS initiation before 2003 & CDS initiation since 2003 \\
\hline 2003 & 345 & 271 & 74 \\
\hline 2004 & 417 & 271 & 146 \\
\hline 2005 & 429 & 256 & 173 \\
\hline 2006 & 436 & 249 & 187 \\
\hline 2007 & 457 & 260 & 197 \\
\hline 2008 & 472 & 266 & 206 \\
\hline 2009 & 454 & 259 & 195 \\
\hline 2010 & 439 & 251 & 188 \\
\hline 2011 & 437 & 248 & 189 \\
\hline 2012 & 428 & 237 & 191 \\
\hline 2013 & 406 & 224 & 182 \\
\hline 2014 & 412 & 228 & 184 \\
\hline 2015 & 400 & 226 & 174 \\
\hline
\end{tabular}

In Panel A of the table, we summarize the sample selection process. In Panel B, we provide information on the incidence of CDS coverage and CDS coverage initiation in our sample of 118,572 firm-year observations from 6,070 firms by fiscal year. 
TABLE 2

Descriptive Statistics

\begin{tabular}{lcccccc}
\hline \hline & $\mathrm{N}$ & Mean & Std. Dev. & $25 \%$ & Median & $75 \%$ \\
\hline$N G$ & 41,424 & 0.014 & 0.025 & 0.004 & 0.013 & 0.023 \\
EXCL & 41,424 & -0.010 & 0.041 & -0.011 & -0.004 & 0.000 \\
TREAT & 41,424 & 0.223 & 0.416 & 0.000 & 0.000 & 0.000 \\
TREAT×POST & 41,424 & 0.206 & 0.404 & 0.000 & 0.000 & 0.000 \\
FOCF ${ }_{t+1}$ & 41,424 & 0.021 & 0.025 & 0.009 & 0.021 & 0.033 \\
FOIN $t+1$ & 41,424 & 0.059 & 0.115 & 0.021 & 0.067 & 0.112 \\
RATED & 41,424 & 0.445 & 0.497 & 0.000 & 0.000 & 1.000 \\
INVGRD & 41,424 & 0.246 & 0.431 & 0.000 & 0.000 & 0.000 \\
LEV & 41,424 & 0.130 & 0.141 & 0.006 & 0.088 & 0.206 \\
MTB & 41,424 & 3.209 & 3.967 & 1.308 & 2.079 & 3.525 \\
MARGIN & 41,424 & -0.023 & 0.742 & 0.004 & 0.053 & 0.116 \\
SIZE & 41,424 & 7.281 & 1.700 & 6.085 & 7.208 & 8.386 \\
SD_RET & 41,424 & 0.024 & 0.014 & 0.015 & 0.020 & 0.029 \\
SALGRW & 41,424 & 1.038 & 0.208 & 0.960 & 1.024 & 1.092 \\
ROA & 41,424 & 0.005 & 0.034 & 0.001 & 0.009 & 0.019 \\
\hline
\end{tabular}

This table presents the descriptive statistics for our sample of 41,424 firm-quarters between fiscal year 2003 and 2015, with earnings announcement dates on or after Mar. 28, 2003 (the enactment date of Reg G). All variables are as defined in Appendix A. 
TABLE 3

CDS Coverage and Non-GAAP Exclusion Quality

\begin{tabular}{|c|c|c|c|c|}
\hline \multicolumn{5}{|c|}{ PANEL A: Predicting one-year-ahead operating cash flows } \\
\hline & $\begin{array}{c}F O C F_{t+1} \\
\text { (1) }\end{array}$ & $\begin{array}{c}F O C F_{t+1} \\
\text { (2) }\end{array}$ & $\begin{array}{c}F O C F_{t+1} \\
\text { (3) }\end{array}$ & $\begin{array}{c}F O C F_{t+1} \\
\text { (4) }\end{array}$ \\
\hline$N G$ & $\begin{array}{c}0.570 * * * \\
(24.28)\end{array}$ & $\begin{array}{c}0.564 * * * \\
(23.08)\end{array}$ & $\begin{array}{c}0.436^{* * * *} \\
(17.09)\end{array}$ & $\begin{array}{c}0.433 * * * \\
(16.69)\end{array}$ \\
\hline$N G \times T R E A T \times P O S T$ & & $\begin{array}{l}0.066 \\
(1.22)\end{array}$ & & $\begin{array}{l}0.038 \\
(0.97)\end{array}$ \\
\hline$E X C L$ & $\begin{array}{c}0.034 * * * \\
(3.96)\end{array}$ & $\begin{array}{c}0.036^{* * *} \\
(3.94)\end{array}$ & $\begin{array}{c}0.017 * * * \\
(2.94)\end{array}$ & $\begin{array}{c}0.019 * * * \\
(3.13)\end{array}$ \\
\hline$E X C L \times T R E A T \times P O S T$ & & $\begin{array}{c}-0.044 * * * \\
(-3.21)\end{array}$ & & $\begin{array}{c}-0.040 * * * \\
(-3.23)\end{array}$ \\
\hline$T R E A T \times P O S T$ & & $\begin{array}{l}0.000 \\
(0.40)\end{array}$ & & $\begin{array}{c}-0.003 * * * \\
(-3.39)\end{array}$ \\
\hline RATED & & & $\begin{array}{l}-0.001 \\
(-1.19)\end{array}$ & $\begin{array}{l}-0.000 \\
(-0.81)\end{array}$ \\
\hline INVGRD & & & $\begin{array}{c}-0.003 * * * \\
(-4.32)\end{array}$ & $\begin{array}{c}-0.002 * * * \\
(-3.57)\end{array}$ \\
\hline$L E V$ & & & $\begin{array}{l}-0.002 \\
(-1.27)\end{array}$ & $\begin{array}{l}-0.002 \\
(-1.11)\end{array}$ \\
\hline$M T B$ & & & $\begin{array}{c}0.000 * * * \\
(8.39)\end{array}$ & $\begin{array}{c}0.000 * * * \\
(8.25)\end{array}$ \\
\hline MARGIN $_{t-1}$ & & & $\begin{array}{c}0.002 * * * \\
(3.96)\end{array}$ & $\begin{array}{c}0.002 * * * \\
(4.01)\end{array}$ \\
\hline SIZE & & & $\begin{array}{c}0.002 * * * \\
(9.83)\end{array}$ & $\begin{array}{c}0.002 * * * \\
(9.93)\end{array}$ \\
\hline$S D \_R E T$ & & & $\begin{array}{c}-0.075 * * * \\
(-4.12)\end{array}$ & $\begin{array}{c}-0.074 * * * \\
(-4.02)\end{array}$ \\
\hline$S A L G R W$ & & & $\begin{array}{c}-0.005 * * * \\
(-6.68)\end{array}$ & $\begin{array}{c}-0.006 * * * \\
(-6.89)\end{array}$ \\
\hline$R O A_{t-1}$ & & & $\begin{array}{c}0.101 * * * \\
(8.59)\end{array}$ & $\begin{array}{c}0.100 * * * \\
(8.53)\end{array}$ \\
\hline Industry Fixed Effects & YES & YES & YES & YES \\
\hline Year-Quarter Fixed Effects & YES & YES & YES & YES \\
\hline$E X C L+E X C L \times T R E A T \times P O S T=0$ & & $p=0.446$ & & $p=0.052$ \\
\hline Adj. $R^{2}$ & $41.48 \%$ & $41.60 \%$ & $46.63 \%$ & $46.71 \%$ \\
\hline $\mathrm{N}$ & 41,424 & 41,424 & 41,424 & 41,424 \\
\hline
\end{tabular}




\begin{tabular}{|c|c|c|c|c|}
\hline \multicolumn{5}{|c|}{ PANEL B: Predicting one-year-ahead operating income } \\
\hline & $\begin{array}{c}\text { FOIN }_{t+1} \\
\text { (1) }\end{array}$ & $\begin{array}{c}\text { FOIN }_{t+1} \\
\text { (2) }\end{array}$ & $\begin{array}{c}\text { FOIN }_{t+1} \\
\text { (3) }\end{array}$ & $\begin{array}{c}\text { FOIN }_{t+1} \\
(4)\end{array}$ \\
\hline$N G$ & $\begin{array}{c}2.841 * * * \\
(26.03)\end{array}$ & $\begin{array}{c}2.801 * * * * \\
(24.81)\end{array}$ & $\begin{array}{c}2.030 * * * \\
(17.82)\end{array}$ & $\begin{array}{c}2.017 * * * * \\
(17.42)\end{array}$ \\
\hline$N G \times T R E A T \times P O S T$ & & $\begin{array}{l}0.379 \\
(1.29)\end{array}$ & & $\begin{array}{l}0.228 \\
(1.09)\end{array}$ \\
\hline$E X C L$ & $\begin{array}{c}0.293 * * * \\
(5.24)\end{array}$ & $\begin{array}{c}0.297 * * * \\
(5.00)\end{array}$ & $\begin{array}{c}0.172 * * * \\
(4.57)\end{array}$ & $\begin{array}{c}0.181 * * * \\
(4.45)\end{array}$ \\
\hline$E X C L \times T R E A T \times P O S T$ & & $\begin{array}{c}-0.168 * * \\
(-2.26)\end{array}$ & & $\begin{array}{c}-0.150 * * \\
(-2.53)\end{array}$ \\
\hline$T R E A T \times P O S T$ & & $\begin{array}{c}0.011 * * \\
(2.35)\end{array}$ & & $\begin{array}{c}-0.008 * * \\
(-2.11)\end{array}$ \\
\hline RATED & & & $\begin{array}{l}0.003 \\
(1.48)\end{array}$ & $\begin{array}{c}0.004^{*} \\
(1.67)\end{array}$ \\
\hline INVGRD & & & $\begin{array}{c}-0.009 * * * \\
(-3.34)\end{array}$ & $\begin{array}{c}-0.008 * * * \\
(-3.14)\end{array}$ \\
\hline$L E V$ & & & $\begin{array}{c}0.035^{* * *} * \\
(4.63)\end{array}$ & $\begin{array}{c}0.036 * * * \\
(4.73)\end{array}$ \\
\hline$M T B$ & & & $\begin{array}{c}0.002 * * * \\
(5.97)\end{array}$ & $\begin{array}{c}0.002 * * * \\
(5.91)\end{array}$ \\
\hline $\operatorname{MARGIN}_{t-1}$ & & & $\begin{array}{c}0.007 * * * \\
(2.88)\end{array}$ & $\begin{array}{c}0.007 * * * \\
(2.92)\end{array}$ \\
\hline SIZE & & & $\begin{array}{c}0.007 * * * \\
(8.54)\end{array}$ & $\begin{array}{c}0.007 * * * \\
(8.39)\end{array}$ \\
\hline$S D \_R E T$ & & & $\begin{array}{c}-1.150 * * * \\
(-14.43)\end{array}$ & $\begin{array}{c}-1.145^{* * *} * \\
(-14.30)\end{array}$ \\
\hline SALGRW & & & $\begin{array}{c}-0.008 * * \\
(-2.25)\end{array}$ & $\begin{array}{c}-0.009 * * \\
(-2.39)\end{array}$ \\
\hline$R O A_{t-1}$ & & & $\begin{array}{c}0.710 * * * \\
(13.97)\end{array}$ & $\begin{array}{c}0.707 * * * \\
(13.99)\end{array}$ \\
\hline Industry Fixed Effects & YES & YES & YES & YES \\
\hline Year-Quarter Fixed Effects & YES & YES & YES & YES \\
\hline$E X C L+E X C L \times T R E A T \times P O S T=0$ & & $p=0.009$ & & $p=0.487$ \\
\hline Adj. $R^{2}$ & $47.31 \%$ & $47.73 \%$ & $55.52 \%$ & $55.55 \%$ \\
\hline $\mathrm{N}$ & 41,424 & 41,424 & 41,424 & 41,424 \\
\hline
\end{tabular}




\begin{tabular}{|c|c|c|c|c|}
\hline \multicolumn{5}{|c|}{ PANEL C: Predicting two- and three-year-ahead operating cash flows and operating income } \\
\hline & $\begin{array}{c}F O C F_{t+1, t+2} \\
(1)\end{array}$ & $\begin{array}{c}F O C F_{t+1, t+3} \\
\text { (2) }\end{array}$ & $\begin{array}{c}\text { FOIN }_{t+1, t+2} \\
\text { (3) }\end{array}$ & $\begin{array}{c}\text { FOIN }_{t+1, t+3} \\
\text { (4) }\end{array}$ \\
\hline$N G$ & $\begin{array}{c}0.370 * * * \\
(13.92)\end{array}$ & $\begin{array}{c}0.322 * * * \\
(11.63)\end{array}$ & $\begin{array}{c}3.585 * * * \\
(14.61)\end{array}$ & $\begin{array}{c}4.673 * * * \\
(12.18)\end{array}$ \\
\hline$N G \times T R E A T \times P O S T$ & $\begin{array}{l}0.038 \\
(1.09)\end{array}$ & $\begin{array}{l}0.045 \\
(1.29)\end{array}$ & $\begin{array}{l}0.469 \\
(1.22)\end{array}$ & $\begin{array}{l}0.813 \\
(1.42)\end{array}$ \\
\hline EXCL & $\begin{array}{c}0.016^{* * *} \\
(2.82)\end{array}$ & $\begin{array}{c}0.017 * * * \\
(2.93)\end{array}$ & $\begin{array}{c}0.270 * * * \\
(3.92)\end{array}$ & $\begin{array}{c}0.406^{* * *} * \\
(4.00)\end{array}$ \\
\hline$E X C L \times T R E A T \times P O S T$ & $\begin{array}{c}-0.041 * * * \\
(-3.36)\end{array}$ & $\begin{array}{c}-0.036^{* * *} \\
(-3.19)\end{array}$ & $\begin{array}{c}-0.346^{* * *} * \\
(-3.22)\end{array}$ & $\begin{array}{c}-0.566 * * * \\
(-3.20)\end{array}$ \\
\hline TREAT $\times P O S T$ & $\begin{array}{c}-0.003 * * * \\
(-3.47)\end{array}$ & $\begin{array}{c}-0.003 * * * \\
(-3.43)\end{array}$ & $\begin{array}{c}-0.015^{* *} \\
(-2.14)\end{array}$ & $\begin{array}{c}-0.027 * * \\
(-2.46)\end{array}$ \\
\hline RATED & $\begin{array}{l}-0.000 \\
(-0.81)\end{array}$ & $\begin{array}{l}-0.001 \\
(-0.83)\end{array}$ & $\begin{array}{l}0.005 \\
(1.01)\end{array}$ & $\begin{array}{l}0.006 \\
(0.67)\end{array}$ \\
\hline INVGRD & $\begin{array}{c}-0.002 * * * \\
(-3.27)\end{array}$ & $\begin{array}{c}-0.002 * * * \\
(-3.03)\end{array}$ & $\begin{array}{c}-0.011 * * \\
(-2.02)\end{array}$ & $\begin{array}{l}-0.015 \\
(-1.62)\end{array}$ \\
\hline$L E V$ & $\begin{array}{l}-0.002 \\
(-0.92)\end{array}$ & $\begin{array}{l}-0.002 \\
(-0.90)\end{array}$ & $\begin{array}{c}0.089 * * * \\
(5.59)\end{array}$ & $\begin{array}{c}0.132 * * * \\
(4.85)\end{array}$ \\
\hline$M T B$ & $\begin{array}{c}0.001 * * * \\
(9.35)\end{array}$ & $\begin{array}{c}0.001 * * * \\
(8.32)\end{array}$ & $\begin{array}{c}0.004 * * * \\
(5.78)\end{array}$ & $\begin{array}{c}0.007 * * * \\
(5.20)\end{array}$ \\
\hline $\operatorname{MARGIN}_{t-1}$ & $\begin{array}{c}0.003 * * * \\
(5.60)\end{array}$ & $\begin{array}{c}0.003 * * * \\
(4.68)\end{array}$ & $\begin{array}{c}0.017 * * * \\
(3.55)\end{array}$ & $\begin{array}{c}0.033 * * * \\
(3.61)\end{array}$ \\
\hline SIZE & $\begin{array}{c}0.002 * * * \\
(9.77)\end{array}$ & $\begin{array}{c}0.002 * * * \\
(9.49)\end{array}$ & $\begin{array}{c}0.016^{* * *} \\
(8.20)\end{array}$ & $\begin{array}{c}0.025 * * * \\
(7.73)\end{array}$ \\
\hline$S D \_R E T$ & $\begin{array}{c}-0.087 * * * \\
(-4.70)\end{array}$ & $\begin{array}{c}-0.086 * * * \\
(-4.37)\end{array}$ & $\begin{array}{c}-2.041 * * * \\
(-13.96)\end{array}$ & $\begin{array}{c}-2.859 * * * \\
(-12.06)\end{array}$ \\
\hline$S A L G R W$ & $\begin{array}{c}-0.005 * * * \\
(-6.32)\end{array}$ & $\begin{array}{c}-0.005 * * * \\
(-6.54)\end{array}$ & $\begin{array}{c}-0.033 * * * \\
(-4.69)\end{array}$ & $\begin{array}{c}-0.061 * * * \\
(-5.67)\end{array}$ \\
\hline$R O A_{t-1}$ & $\begin{array}{c}0.086^{* * * *} \\
(7.27)\end{array}$ & $\begin{array}{c}0.078 * * * \\
(6.34)\end{array}$ & $\begin{array}{c}1.259 * * * \\
(11.79)\end{array}$ & $\begin{array}{c}1.702 * * * \\
(9.97)\end{array}$ \\
\hline $\begin{array}{l}\text { Industry Fixed Effects } \\
\text { Year-Quarter Fixed Effects }\end{array}$ & $\begin{array}{l}\text { YES } \\
\text { YES }\end{array}$ & $\begin{array}{l}\text { YES } \\
\text { YES }\end{array}$ & $\begin{array}{l}\text { YES } \\
\text { YES }\end{array}$ & $\begin{array}{l}\text { YES } \\
\text { YES }\end{array}$ \\
\hline$E X C L+E X C L \times T R E A T \times P O S T=0$ & $p=0.019$ & $p=0.050$ & $p=0.364$ & $p=0.271$ \\
\hline $\begin{array}{l}\text { Adj. } \mathrm{R}^{2} \\
\mathrm{~N}\end{array}$ & $\begin{array}{c}47.16 \% \\
38,638\end{array}$ & $\begin{array}{r}46.77 \% \\
32,379\end{array}$ & $\begin{array}{l}53.24 \% \\
38,280\end{array}$ & $\begin{array}{l}50.84 \% \\
31,807\end{array}$ \\
\hline
\end{tabular}

This table presents the results of estimating the association between CDS coverage and firms' non-GAAP disclosure quality based on OLS regression analyses. Non-GAAP disclosure quality is measured with the predictability of non-GAAP earnings components on future operating cash flows or future operating earnings aggregated over the following 1,2, and 3 years. T-statistics are reported in parentheses below the regression coefficients. P-values are based on two-tailed t-statistics with standard errors clustered by firm. $* * *, * * *$ denote significance at the $10 \%, 5 \%$, and $1 \%$ levels, respectively. Industry fixed effects are based on the 2-digit SIC code. All variables are defined as in Appendix A. 


\section{TABLE 4}

CDS Coverage Initiation and Non-GAAP Exclusion Quality

Excluding Firms with CDS Coverage throughout the Sample Period

\begin{tabular}{|c|c|c|c|c|}
\hline \multicolumn{5}{|c|}{ PANEL A: Predicting one-year-ahead operating cash flows } \\
\hline & $\begin{array}{c}F O C F_{t+1} \\
(1) \\
\end{array}$ & $\begin{array}{c}F O C F_{t+1} \\
(2)\end{array}$ & $\begin{array}{c}F O C F_{t+1} \\
(3)\end{array}$ & $\begin{array}{c}F O C F_{t+1} \\
(4)\end{array}$ \\
\hline$N G$ & $\begin{array}{c}0.431 * * * \\
(16.42)\end{array}$ & $\begin{array}{c}0.431 * * * \\
(16.45)\end{array}$ & $\begin{array}{c}0.431 * * * \\
(16.46)\end{array}$ & $\begin{array}{c}0.431 * * * \\
(16.48)\end{array}$ \\
\hline$N G \times T R E A T \times P O S T$ & $\begin{array}{l}0.070 \\
(1.23)\end{array}$ & & & \\
\hline$E X C L$ & $\begin{array}{l}0.018 * * * \\
(3.02)\end{array}$ & $\begin{array}{l}0.018 * * * \\
(3.00)\end{array}$ & $\begin{array}{l}0.018 * * * \\
(3.00)\end{array}$ & $\begin{array}{l}0.018 * * * \\
(2.99)\end{array}$ \\
\hline$E X C L \times T R E A T \times P O S T$ & $\begin{array}{c}-0.063 * * * \\
(-3.50)\end{array}$ & & & \\
\hline$T R E A T \times P O S T$ & $\begin{array}{l}-0.002 * * \\
(-2.00)\end{array}$ & & & \\
\hline$N G \times F 1 Y$ & & $\begin{array}{l}0.067 \\
(1.25)\end{array}$ & & \\
\hline$E X C L \times F 1 Y$ & & $\begin{array}{c}-0.061 * * * \\
(-3.08)\end{array}$ & & \\
\hline F1Y & & $\begin{array}{c}-0.002 * * \\
(-1.96)\end{array}$ & & \\
\hline$N G \times F 2 Y$ & & & $\begin{array}{l}0.071 \\
(1.34)\end{array}$ & \\
\hline$E X C L \times F 2 Y$ & & & $\begin{array}{c}-0.063 * * * \\
(-3.13)\end{array}$ & \\
\hline$F 2 Y$ & & & $\begin{array}{r}-0.002 * \\
(-1.89)\end{array}$ & \\
\hline$N G \times F 3 Y$ & & & & $\begin{array}{l}0.059 \\
(1.16)\end{array}$ \\
\hline$E X C L \times F 3 Y$ & & & & $\begin{array}{c}-0.067 * * * \\
(-2.94)\end{array}$ \\
\hline$F 3 Y$ & & & & $\begin{array}{l}-0.002 \\
(-1.53)\end{array}$ \\
\hline Controls & YES & YES & YES & YES \\
\hline Industry Fixed Effects & YES & YES & YES & YES \\
\hline Year-Quarter Fixed Effects & YES & YES & YES & YES \\
\hline $\begin{array}{l}E X C L+E X C L \times T R E A T \times P O S T=0 \\
E X C L+E X C L \times F 1 / 2 / 3 Y=0\end{array}$ & $p=0.008$ & $p=0.023$ & $p=0.019$ & $p=0.025$ \\
\hline Adj. $R^{2}$ & $46.51 \%$ & $46.50 \%$ & $46.50 \%$ & $46.49 \%$ \\
\hline $\mathrm{N}$ & 36,522 & 36,522 & 36,522 & 36,522 \\
\hline
\end{tabular}




\begin{tabular}{|c|c|c|c|c|}
\hline \multicolumn{5}{|c|}{ PANEL B: Predicting one-year-ahead operating income } \\
\hline & $\begin{array}{l}\text { FOIN }_{t+1} \\
(1)\end{array}$ & $\begin{array}{l}\text { FOIN }_{t+1} \\
(2)\end{array}$ & $\begin{array}{l}F O I N_{t+1} \\
\quad(3)\end{array}$ & $\begin{array}{c}\text { FOIN }_{t+1} \\
\quad(4)\end{array}$ \\
\hline$N G$ & $\begin{array}{l}2.005 * * * \\
(17.14)\end{array}$ & $\begin{array}{l}2.008 * * * \\
(17.17)\end{array}$ & $\begin{array}{l}2.009 * * * \\
(17.19)\end{array}$ & $\begin{array}{c}2.012^{* * * *} \\
(17.21)\end{array}$ \\
\hline$N G \times T R E A T \times P O S T$ & $\begin{array}{l}0.290 \\
(0.90)\end{array}$ & & & \\
\hline$E X C L$ & $\begin{array}{c}0.173 * * * \\
(4.35)\end{array}$ & $\begin{array}{c}0.173 * * * \\
(4.35)\end{array}$ & $\begin{array}{l}0.172 * * * \\
(4.35)\end{array}$ & $\begin{array}{l}0.172 * * * \\
\quad(4.35)\end{array}$ \\
\hline EXCL $\times T R E A T \times P O S T$ & $\begin{array}{c}-0.196 * * \\
(-2.28)\end{array}$ & & & \\
\hline TREAT $\times P O S T$ & $\begin{array}{l}-0.004 \\
(-0.76)\end{array}$ & & & \\
\hline$N G \times F 1 Y$ & & $\begin{array}{l}0.227 \\
(0.73)\end{array}$ & & \\
\hline$E X C L \times F 1 Y$ & & $\begin{array}{c}-0.182 * * \\
(-2.01)\end{array}$ & & \\
\hline$F 1 Y$ & & $\begin{array}{l}-0.002 \\
(-0.45)\end{array}$ & & \\
\hline$N G \times F 2 Y$ & & & $\begin{array}{l}0.180 \\
(0.58)\end{array}$ & \\
\hline$E X C L \times F 2 Y$ & & & $\begin{array}{c}-0.176^{*} \\
(-1.88)\end{array}$ & \\
\hline$F 2 Y$ & & & $\begin{array}{l}-0.002 \\
(-0.28)\end{array}$ & \\
\hline$N G \times F 3 Y$ & & & & $\begin{array}{l}0.068 \\
(0.24)\end{array}$ \\
\hline$E X C L \times F 3 Y$ & & & & $\begin{array}{c}-0.193 * \\
(-1.88)\end{array}$ \\
\hline F3Y & & & & $\begin{array}{l}-0.000 \\
(-0.03)\end{array}$ \\
\hline Controls & YES & YES & YES & YES \\
\hline Industry Fixed Effects & YES & YES & YES & YES \\
\hline Year-Quarter Fixed Effects & YES & YES & YES & YES \\
\hline $\begin{array}{l}E X C L+E X C L \times T R E A T \times P O S T=0 \\
E X C L+E X C L \times F 1 / 2 / 3 Y=0\end{array}$ & $p=0.771$ & $p=0.907$ & $p=0.969$ & $p=0.829$ \\
\hline $\begin{array}{l}\text { Adj. } R^{2} \\
N\end{array}$ & $\begin{array}{l}55.33 \% \\
36,522\end{array}$ & $\begin{array}{l}55.32 \% \\
36,522\end{array}$ & $\begin{array}{l}55.32 \% \\
36,522\end{array}$ & $\begin{array}{l}55.32 \% \\
36,522\end{array}$ \\
\hline
\end{tabular}

This table presents the results of estimating the association between CDS coverage and firms' nonGAAP disclosure quality based on OLS regression analyses, excluding firms with CDS coverage throughout the sample period. T-statistics are reported in parentheses below the regression coefficients. $\mathrm{P}$-values are based on two-tailed $\mathrm{t}$-statistics with standard errors clustered by firm. *, **, *** denote significance at the $10 \%, 5 \%$, and $1 \%$ levels, respectively. Industry fixed effects are based on the 2-digit SIC code. All variables are defined as in Appendix A. 
TABLE 5

CDS Coverage and Non-GAAP Exclusion Quality - Partition Based on Investment Grade

\begin{tabular}{|c|c|c|c|c|}
\hline & \multicolumn{2}{|c|}{$F O C F_{t+1}$} & \multicolumn{2}{|c|}{$F O I N_{t+1}$} \\
\hline & $\begin{array}{c}I N V G R D=1 \\
(1)\end{array}$ & $\begin{array}{c}I N V G R D=0 \\
(2)\end{array}$ & $\begin{array}{c}I N V G R D=1 \\
\text { (3) }\end{array}$ & $\begin{array}{c}I N V G R D=0 \\
(4)\end{array}$ \\
\hline$N G$ & $\begin{array}{c}0.404 * * * \\
(5.73)\end{array}$ & $\begin{array}{c}0.429 * * * \\
(16.11)\end{array}$ & $\begin{array}{c}1.736^{* * * *} \\
(4.67)\end{array}$ & $\begin{array}{c}2.003 * * * \\
(16.78)\end{array}$ \\
\hline$N G \times T R E A T \times P O S T$ & $\begin{array}{l}-0.049 \\
(-0.85)\end{array}$ & $\begin{array}{c}0.139 * * * \\
(2.84)\end{array}$ & $\begin{array}{l}0.016 \\
(0.05)\end{array}$ & $\begin{array}{c}0.523^{*} \\
(1.93)\end{array}$ \\
\hline$E X C L$ & $\begin{array}{c}-0.049 * * \\
(-2.14)\end{array}$ & $\begin{array}{c}0.019 * * * \\
(3.11)\end{array}$ & $\begin{array}{c}0.533 * * \\
(2.13)\end{array}$ & $\begin{array}{c}0.167 * * * \\
(4.21)\end{array}$ \\
\hline$E X C L \times T R E A T \times P O S T$ & $\begin{array}{l}0.034 \\
(1.31)\end{array}$ & $\begin{array}{c}-0.050 * * * \\
(-3.16)\end{array}$ & $\begin{array}{l}-0.331 \\
(-1.26)\end{array}$ & $\begin{array}{c}-0.244 * * * \\
(-3.92)\end{array}$ \\
\hline TREAT $\times P O S T$ & $\begin{array}{l}0.000 \\
(0.09)\end{array}$ & $\begin{array}{c}-0.005 * * * \\
(-4.84)\end{array}$ & $\begin{array}{l}-0.003 \\
(-0.55)\end{array}$ & $\begin{array}{c}-0.013 * * * \\
(-3.03)\end{array}$ \\
\hline RATED & & $\begin{array}{l}-0.001 \\
(-1.60)\end{array}$ & & $\begin{array}{l}0.000 \\
(0.12)\end{array}$ \\
\hline$L E V$ & $\begin{array}{c}-0.016^{* * *} \\
(-4.31)\end{array}$ & $\begin{array}{l}-0.001 \\
(-0.28)\end{array}$ & $\begin{array}{c}-0.031 * \\
(-1.80)\end{array}$ & $\begin{array}{c}0.047 * * * \\
(5.67)\end{array}$ \\
\hline$M T B$ & $\begin{array}{c}0.001 * * * \\
(6.79)\end{array}$ & $\begin{array}{c}0.000 * * * \\
(6.06)\end{array}$ & $\begin{array}{c}0.005^{* * *} * \\
\quad(9.60)\end{array}$ & $\begin{array}{c}0.001 * * * \\
(3.53)\end{array}$ \\
\hline MARGIN $_{t-1}$ & $\begin{array}{l}-0.001 \\
(-0.88)\end{array}$ & $\begin{array}{c}0.002 * * * \\
(4.14)\end{array}$ & $\begin{array}{c}-0.008^{*} \\
(-1.71)\end{array}$ & $\begin{array}{c}0.008 * * * \\
(3.09)\end{array}$ \\
\hline SIZE & $\begin{array}{l}-0.000 \\
(-0.20)\end{array}$ & $\begin{array}{c}0.003 * * * \\
(10.98)\end{array}$ & $\begin{array}{l}-0.001 \\
(-0.63)\end{array}$ & $\begin{array}{c}0.010 * * * \\
(9.39)\end{array}$ \\
\hline$S D \_R E T$ & $\begin{array}{l}-0.028 \\
(-1.16)\end{array}$ & $\begin{array}{c}-0.064 * * * \\
(-3.07)\end{array}$ & $\begin{array}{c}-0.408 * * * \\
(-4.25)\end{array}$ & $\begin{array}{c}-1.199 * * * \\
(-13.19)\end{array}$ \\
\hline$S A L G R W$ & $\begin{array}{c}-0.004 * * * \\
(-3.41)\end{array}$ & $\begin{array}{c}-0.006 * * * \\
(-6.20)\end{array}$ & $\begin{array}{c}-0.012 * * \\
(-2.35)\end{array}$ & $\begin{array}{c}-0.007 * \\
(-1.69)\end{array}$ \\
\hline$R O A_{t-1}$ & $\begin{array}{c}0.108 * * * \\
(5.54)\end{array}$ & $\begin{array}{c}0.095 * * * \\
(7.68)\end{array}$ & $\begin{array}{c}0.688 * * * \\
(8.36)\end{array}$ & $\begin{array}{c}0.679 * * * \\
(12.85)\end{array}$ \\
\hline Industry Fixed Effects & YES & YES & YES & YES \\
\hline Year-Quarter Fixed Effects & YES & YES & YES & YES \\
\hline$E X C L+E X C L \times T R E A T \times P O S T=0$ & $p=0.280$ & $p=0.034$ & $p=0.016$ & $p=0.117$ \\
\hline $\begin{array}{l}\text { Adj. } \mathrm{R}^{2} \\
\mathrm{~N}\end{array}$ & $\begin{array}{c}60.44 \% \\
10,188\end{array}$ & $\begin{array}{c}45.91 \% \\
31,236\end{array}$ & $\begin{array}{c}62.99 \% \\
10,188\end{array}$ & $\begin{array}{c}55.00 \% \\
31,236\end{array}$ \\
\hline
\end{tabular}

This table presents the results of estimating the association between CDS coverage and firms' non-GAAP disclosure quality based on OLS regression analyses, with the sample partitioned based on investment grade (INVGRD). T-statistics are reported in parentheses below the regression coefficients. P-values are based on two-tailed t-statistics with standard errors clustered by firm. *,**,*** denote significance at the $10 \%, 5 \%$, and $1 \%$ levels, respectively. Industry fixed effects are based on the 2-digit SIC code. All variables are defined as in Appendix A. 
TABLE 6

DID Analysis with Entropy Balancing

\begin{tabular}{lcc}
\hline \hline \multicolumn{3}{c}{ Panel A: Distribution of treatment and control groups } \\
\hline Year & Treatment & Control \\
\hline 2003 & 95 & 1,405 \\
2004 & 103 & 1,492 \\
2005 & 127 & 1,658 \\
2006 & 127 & 2,178 \\
2007 & 113 & 2,155 \\
2008 & 128 & 2,550 \\
2009 & 130 & 2,663 \\
2010 & 140 & 2,606 \\
2011 & 124 & 2,842 \\
2012 & 133 & 2,989 \\
2013 & 109 & 3,163 \\
2014 & 112 & 3,162 \\
2015 & 123 & 3,332 \\
Total & 1,564 & 32,195 \\
\hline
\end{tabular}

\begin{tabular}{|c|c|c|c|c|c|c|}
\hline \multicolumn{7}{|c|}{ Panel B: Firm characteristics of treatment and EB-reweighted control groups } \\
\hline & \multicolumn{3}{|c|}{ Treatment } & \multicolumn{3}{|c|}{ EB Reweighted Control } \\
\hline & $\begin{array}{c}\text { Mean } \\
(1)\end{array}$ & $\begin{array}{l}\text { Variance } \\
\text { (2) }\end{array}$ & $\begin{array}{c}\text { Skewness } \\
\text { (3) }\end{array}$ & $\begin{array}{c}\text { Mean } \\
(4)\end{array}$ & $\begin{array}{c}\text { Variance } \\
\text { (5) }\end{array}$ & $\begin{array}{c}\text { Skewness } \\
(6)\end{array}$ \\
\hline RATED & 0.882 & 0.104 & -2.364 & 0.882 & 0.104 & -2.363 \\
\hline INVGRD & 0.595 & 0.241 & -0.388 & 0.595 & 0.241 & -0.388 \\
\hline$L E V$ & 0.144 & 0.013 & 1.087 & 0.144 & 0.013 & 0.960 \\
\hline MTB & 2.847 & 9.359 & 4.631 & 2.847 & 9.359 & 5.558 \\
\hline MARGIN $_{t-1}$ & 0.077 & 0.059 & -7.452 & 0.077 & 0.059 & -6.055 \\
\hline SIZE & 8.520 & 1.582 & 0.106 & 8.519 & 1.582 & -0.008 \\
\hline$S D \_R E T$ & 0.021 & 0.000 & 3.088 & 0.021 & 0.000 & 2.843 \\
\hline$S A \bar{L} G R W$ & 1.026 & 0.032 & 0.895 & 1.026 & 0.032 & 1.927 \\
\hline$R O A_{t-1}$ & 0.011 & 0.001 & -2.800 & 0.011 & 0.001 & -3.347 \\
\hline $\mathrm{N}$ & \multicolumn{3}{|c|}{1,564} & \multicolumn{3}{|c|}{32,195} \\
\hline
\end{tabular}




\begin{tabular}{|c|c|c|c|c|}
\hline \multicolumn{5}{|c|}{ Panel C: CDS coverage and Non-GAAP exclusion quality - Partition based on investment grade } \\
\hline & \multicolumn{2}{|c|}{$F O C F_{t+1}$} & \multicolumn{2}{|c|}{ FOIN ${ }_{t+1}$} \\
\hline & $\begin{array}{c}I N V G R D=1 \\
(1)\end{array}$ & $\begin{array}{c}I N V G R D=0 \\
\text { (2) }\end{array}$ & $\begin{array}{c}I N V G R D=1 \\
\text { (3) }\end{array}$ & $\begin{array}{c}I N V G R D=0 \\
\text { (4) }\end{array}$ \\
\hline$N G$ & $\begin{array}{c}0.923 * * * \\
(5.35)\end{array}$ & $\begin{array}{c}0.553 * * * \\
(2.98)\end{array}$ & $\begin{array}{c}3.562 * * * \\
(3.65)\end{array}$ & $\begin{array}{c}3.190 * * * \\
(6.38)\end{array}$ \\
\hline$N G \times T R E A T$ & $\begin{array}{c}0.051 \\
(0.50)\end{array}$ & $\begin{array}{l}-0.085 \\
(-1.17)\end{array}$ & $\begin{array}{l}-0.024 \\
(-0.07)\end{array}$ & $\begin{array}{l}0.140 \\
(0.31)\end{array}$ \\
\hline$N G \times T R E A T \times P O S T$ & $\begin{array}{l}-0.018 \\
(-0.21)\end{array}$ & $\begin{array}{c}0.178^{*} \\
(1.94)\end{array}$ & $\begin{array}{l}0.207 \\
(0.63)\end{array}$ & $\begin{array}{l}-0.060 \\
(-0.13)\end{array}$ \\
\hline EXCL & $\begin{array}{c}0.605 * * * \\
(8.09)\end{array}$ & $\begin{array}{c}-0.089 * * * \\
(-3.21)\end{array}$ & $\begin{array}{l}0.456 \\
(1.19)\end{array}$ & $\begin{array}{c}-0.391 * * * \\
(-2.88)\end{array}$ \\
\hline$E X C L \times T R E A T$ & $\begin{array}{l}-0.034 \\
(-0.96)\end{array}$ & $\begin{array}{c}0.054 * * * \\
(2.68)\end{array}$ & $\begin{array}{l}0.068 \\
(0.42)\end{array}$ & $\begin{array}{l}0.062 \\
(0.45)\end{array}$ \\
\hline$E X C L \times T R E A T \times P O S T$ & $\begin{array}{c}0.132 * * * \\
(2.85)\end{array}$ & $\begin{array}{c}-0.090 * * * \\
(-3.40)\end{array}$ & $\begin{array}{l}-0.008 \\
(-0.02)\end{array}$ & $\begin{array}{c}-0.311^{* *} \\
(-2.02)\end{array}$ \\
\hline TREAT & $\begin{array}{l}-0.000 \\
(-0.07)\end{array}$ & $\begin{array}{c}0.011 * * * \\
(3.94)\end{array}$ & $\begin{array}{l}0.005 \\
(0.73)\end{array}$ & $\begin{array}{l}0.013 \\
(1.60)\end{array}$ \\
\hline TREAT $\times P O S T$ & $\begin{array}{l}0.002 \\
(0.74)\end{array}$ & $\begin{array}{c}-0.010 * * * \\
(-2.84)\end{array}$ & $\begin{array}{l}-0.007 \\
(-1.14)\end{array}$ & $\begin{array}{c}-0.015^{* *} \\
(-2.03)\end{array}$ \\
\hline RATED & & $\begin{array}{l}-0.002 \\
(-1.54)\end{array}$ & & $\begin{array}{l}0.006 \\
(1.22)\end{array}$ \\
\hline$L E V$ & $\begin{array}{c}-0.014 * * \\
(-2.25)\end{array}$ & $\begin{array}{c}-0.014 * * * \\
(-3.48)\end{array}$ & $\begin{array}{l}0.022 \\
(0.91)\end{array}$ & $\begin{array}{l}-0.023 \\
(-1.25)\end{array}$ \\
\hline$M T B$ & $\begin{array}{c}0.001 * * * \\
(4.39)\end{array}$ & $\begin{array}{l}0.000 \\
(1.45)\end{array}$ & $\begin{array}{c}0.006 * * * \\
(6.26)\end{array}$ & $\begin{array}{c}0.003 * * * \\
(4.62)\end{array}$ \\
\hline$M_{A R G I N_{t-1}}$ & $\begin{array}{c}-0.004 * * \\
(-2.01)\end{array}$ & $\begin{array}{c}-0.004 * * \\
(-2.04)\end{array}$ & $\begin{array}{l}-0.007 \\
(-0.53)\end{array}$ & $\begin{array}{l}-0.009 \\
(-1.43)\end{array}$ \\
\hline SIZE & $\begin{array}{l}0.000 \\
(0.03)\end{array}$ & $\begin{array}{l}0.001 \\
(0.92)\end{array}$ & $\begin{array}{l}-0.002 \\
(-0.84)\end{array}$ & $\begin{array}{l}0.002 \\
(0.97)\end{array}$ \\
\hline$S D \_R E T$ & $\begin{array}{l}-0.062 \\
(-1.61)\end{array}$ & $\begin{array}{c}-0.082 * * * \\
(-2.88)\end{array}$ & $\begin{array}{c}-0.402 * * * \\
(-3.19)\end{array}$ & $\begin{array}{c}-1.532 * * * \\
(-8.36)\end{array}$ \\
\hline$S A L G R W$ & $\begin{array}{c}-0.004 * * \\
(-2.26)\end{array}$ & $\begin{array}{c}-0.007 * * * \\
(-5.10)\end{array}$ & $\begin{array}{l}-0.009 \\
(-1.12)\end{array}$ & $\begin{array}{c}-0.025^{* * *} \\
(-3.59)\end{array}$ \\
\hline$R O A_{t-1}$ & $\begin{array}{c}0.098 * * * \\
(4.35)\end{array}$ & $\begin{array}{c}0.061 * * * \\
(3.36)\end{array}$ & $\begin{array}{c}0.441 * * * \\
(3.07)\end{array}$ & $\begin{array}{c}0.299 * * * \\
(3.99)\end{array}$ \\
\hline $\begin{array}{l}N G \times \text { Year-Quarter Fixed Effects } \\
E X C L \times \text { Year-Quarter Fixed Effects } \\
\text { Industry Fixed Effects } \\
\text { Year-Quarter Fixed Effects }\end{array}$ & $\begin{array}{l}\text { YES } \\
\text { YES } \\
\text { YES } \\
\text { YES }\end{array}$ & $\begin{array}{l}\text { YES } \\
\text { YES } \\
\text { YES } \\
\text { YES }\end{array}$ & $\begin{array}{l}\text { YES } \\
\text { YES } \\
\text { YES } \\
\text { YES }\end{array}$ & $\begin{array}{l}\text { YES } \\
\text { YES } \\
\text { YES } \\
\text { YES }\end{array}$ \\
\hline $\begin{array}{l}E X C L \times(T R E A T+T R E A T \times P O S T)=0 \\
E X C L \times(1+T R E A T+T R E A T \times P O S T)=0\end{array}$ & $\begin{array}{l}p=0.042 \\
p=0.000\end{array}$ & $\begin{array}{l}p=0.132 \\
p=0.000\end{array}$ & $\begin{array}{l}p=0.880 \\
p=0.309\end{array}$ & $\begin{array}{l}p=0.006 \\
p=0.000\end{array}$ \\
\hline $\begin{array}{l}\text { Adj. } \mathrm{R}^{2} \\
\mathrm{~N}\end{array}$ & $\begin{array}{c}68.90 \% \\
4,611 \\
\end{array}$ & $\begin{array}{c}61.26 \% \\
29,148 \\
\end{array}$ & $\begin{array}{c}71.60 \% \\
4,611 \\
\end{array}$ & $\begin{array}{c}59.43 \% \\
29,148\end{array}$ \\
\hline
\end{tabular}


This table presents the analyses with entropy balancing (EB) adjusting and Difference-in-Difference (DID) design. Panel A presents the distribution of the treatment and control groups used in the EB and DID analyses. Firms that have experienced CDS initiation during the sample period and have at least data in at least four of the eight quarters immediately preceding and in at least four of the eight quarters immediately following CDS coverage initiation are identified as treatment firms. Firms with CDS coverage throughout the sample period are excluded from the analyses. Units in the control group are reweighted applying the EB scheme to achieve balanced covariate distributions. In the EB analyses, we condition the reweighting on the first and second moments of covariates, and their distributions are reported in Panel B. Firm characteristics used in the EB analyses include RATED, INVGRD, LEV, MTB, MARGIN ${ }_{t-1}$, SIZE, SD_RET, SALGRW, and ROA $A_{t-1}$. Panel C presents the results of estimating the association between firms' non-GAAP disclosure quality and CDS initiation within sub-samples partitioned based on investment grade (INVGRD). Entropy balancing of control observations is applied first, followed by the separation of investment-grade observations from non-investmentgrade observations, followed by the DID analyses. T-statistics are reported in parentheses below the regression coefficients. P-values are based on two-tailed t-statistics with standard errors clustered by firm. *, **, and *** denote significance at the $10 \%, 5 \%$, and $1 \%$ levels, respectively. Industry fixed effects are based on the 2-digit SIC code. All variables are defined as in Appendix A. 
TABLE 7

Frequency of Non-GAAP Earnings Disclosure and Management Earnings Forecasts

\begin{tabular}{|c|c|c|c|c|}
\hline & \multicolumn{2}{|c|}{ Full Sample } & \multicolumn{2}{|c|}{ EB Analysis Sample } \\
\hline & $\begin{array}{c}\text { Non-GAAP } \\
(1)\end{array}$ & $\begin{array}{c}\text { Number of } \\
\text { Forecasts } \\
(2)\end{array}$ & $\begin{array}{c}\text { Non-GAAP } \\
\text { (3) }\end{array}$ & $\begin{array}{c}\text { Number of } \\
\text { Forecasts } \\
\text { (4) }\end{array}$ \\
\hline$T R E A T \times P O S T$ & $\begin{array}{l}-0.023 \\
(-1.26)\end{array}$ & $\begin{array}{c}0.036 * * * \\
(3.62)\end{array}$ & $\begin{array}{c}-0.126 * * * \\
(-3.52)\end{array}$ & $\begin{array}{l}0.022 \\
(0.83)\end{array}$ \\
\hline TREAT & & & $\begin{array}{l}0.127 * * * \\
\quad(3.38)\end{array}$ & $\begin{array}{l}-0.010 \\
(-0.41)\end{array}$ \\
\hline RATED & $\begin{array}{c}0.076^{* * * *} \\
(5.26)\end{array}$ & $\begin{array}{l}-0.005 \\
(-0.86)\end{array}$ & $\begin{array}{l}0.006 \\
(0.13)\end{array}$ & $\begin{array}{l}-0.002 \\
(-0.07)\end{array}$ \\
\hline$I N V G R D$ & $\begin{array}{c}-0.053 * * * \\
(-2.87)\end{array}$ & $\begin{array}{c}0.044 * * * \\
(4.95)\end{array}$ & $\begin{array}{l}-0.000 \\
(-0.01)\end{array}$ & $\begin{array}{l}0.030 \\
(1.58)\end{array}$ \\
\hline$L E V$ & $\begin{array}{c}0.288 * * * \\
(8.07)\end{array}$ & $\begin{array}{c}0.033 * * \\
(2.53)\end{array}$ & $\begin{array}{c}0.285 * * \\
(2.06)\end{array}$ & $\begin{array}{l}0.077 \\
(0.75)\end{array}$ \\
\hline$M T B$ & $\begin{array}{c}-0.007 * * * \\
(-6.75)\end{array}$ & $\begin{array}{l}-0.000 \\
(-0.51)\end{array}$ & $\begin{array}{l}-0.005 \\
(-1.55)\end{array}$ & $\begin{array}{l}-0.001 \\
(-0.47)\end{array}$ \\
\hline $\operatorname{MARGIN}_{t-1}$ & $\begin{array}{c}0.019 * * * \\
(15.25)\end{array}$ & $\begin{array}{c}0.001 * * \\
(2.28)\end{array}$ & $\begin{array}{c}0.164 * * * \\
(3.34)\end{array}$ & $\begin{array}{l}-0.047 \\
(-1.16)\end{array}$ \\
\hline SIZE & $\begin{array}{c}0.068 * * * \\
(19.68)\end{array}$ & $\begin{array}{c}0.022 * * * \\
(13.87)\end{array}$ & $\begin{array}{c}0.034 * \\
(1.92)\end{array}$ & $\begin{array}{c}0.027 * * \\
(2.26)\end{array}$ \\
\hline$S D \_R E T$ & $\begin{array}{l}0.198 \\
(0.91)\end{array}$ & $\begin{array}{l}0.182 * * \\
(2.10)\end{array}$ & $\begin{array}{l}0.541 \\
(0.65)\end{array}$ & $\begin{array}{l}0.244 \\
(0.49)\end{array}$ \\
\hline$S A L G R W$ & $\begin{array}{l}-0.007 \\
(-1.35)\end{array}$ & $\begin{array}{c}0.010 * * * \\
(3.40)\end{array}$ & $\begin{array}{l}-0.006 \\
(-0.27)\end{array}$ & $\begin{array}{l}0.013 \\
(0.96)\end{array}$ \\
\hline$R O A_{t-1}$ & $\begin{array}{c}-0.773 * * * \\
(-9.65)\end{array}$ & $\begin{array}{c}0.166^{* * * *} \\
(6.71)\end{array}$ & $\begin{array}{c}-2.541 * * * \\
(-5.06)\end{array}$ & $\begin{array}{l}0.410 \\
(1.11)\end{array}$ \\
\hline $\begin{array}{l}\text { Industry Fixed Effects } \\
\text { Year-Quarter Fixed Effects }\end{array}$ & $\begin{array}{l}\text { YES } \\
\text { YES }\end{array}$ & $\begin{array}{l}\text { YES } \\
\text { YES }\end{array}$ & $\begin{array}{l}\text { YES } \\
\text { YES }\end{array}$ & $\begin{array}{l}\text { YES } \\
\text { YES }\end{array}$ \\
\hline$T R E A T+T R E A T \times P O S T=0$ & & & $p=0.983$ & $p=0.655$ \\
\hline $\begin{array}{l}\text { Adj. } \mathrm{R}^{2} \\
\mathrm{~N}\end{array}$ & $\begin{array}{l}20.99 \% \\
118,572 \\
\end{array}$ & $\begin{array}{c}8.57 \% \\
118,572 \\
\end{array}$ & $\begin{array}{l}23.18 \% \\
103,151 \\
\end{array}$ & $\begin{array}{c}9.96 \% \\
103,151 \\
\end{array}$ \\
\hline
\end{tabular}

This table presents the results of estimating the association between voluntary disclosure (i.e., non-GAAP reporting and management earnings forecasts) frequency and CDS coverage controlling for other firm characteristics. Non-GAAP is an indicator variable that equals to one if the firm has non-GAAP disclosure during a quarter, and zero otherwise. Number of Forecasts is calculated as $\log (1+$ the number of EPS forecasts issued by managers). Follow prior literature, we exclude EPS forecasts issued between the fiscal-period end and the earnings announcement date (i.e., preannouncements) because these forecasts are considered part of firms' earnings announcement strategies rather than voluntary disclosure activities (Kim et al. [2018]). Estimations in columns 1 and 2 are based on the full sample, and those in columns 3 and 4 are based on the entropy-balancing (EB) analysis subsample. Note that firms that have CDS coverage throughout the sample period are excluded from the EB analyses in columns 3 and 4. Units in the control group are reweighted applying the EB scheme to achieve balanced covariate distributions. Tstatistics are reported in parentheses below the OLS regression coefficients. P-values are based on two- 
tailed t-statistics with standard errors clustered by firm. *, **, and *** denote significance at the $10 \%$, $5 \%$, and $1 \%$ levels, respectively. Industry fixed effects are based on the 2-digit SIC code. All variables are defined as in Appendix A. 